Illinois State University

ISU ReD: Research and eData

Theses and Dissertations

4-19-2021

\title{
Isolating Locations of Potential Episodes of Cave Collapse and Their Relationship to Cave Level Development Through Major River System Incisions
}

Ethan William Conley

Illinois State University, conleyew23@gmail.com

Follow this and additional works at: https://ir.library.illinoisstate.edu/etd

\section{Recommended Citation}

Conley, Ethan William, "Isolating Locations of Potential Episodes of Cave Collapse and Their Relationship to Cave Level Development Through Major River System Incisions" (2021). Theses and Dissertations. 1431.

https://ir.library.illinoisstate.edu/etd/1431

This Thesis is brought to you for free and open access by ISU ReD: Research and eData. It has been accepted for inclusion in Theses and Dissertations by an authorized administrator of ISU ReD: Research and eData. For more information, please contact ISUReD@ilstu.edu. 
ISOLATING LOCATIONS OF POTENTIAL EPISODES OF CAVE COLLAPSE AND THEIR

RELATIONSHIP TO CAVE LEVEL DEVELOPMENT THROUGH MAJOR RIVER SYSTEM

INCISIONS

\section{ETHAN WILLIAM CONLEY}

\section{Pages}

Karst landscapes, in which dissolution of bedrock is the dominant geomorphic process, make up 10\%-20\% of Earth's land surfaces and supply between $20 \%-25 \%$ of the global population with drinking water. Dissolution dominates the genesis of karst systems, creating flow pathways, conduits, and caves. Cave patterns from dissolution can be influenced by regional factors, such as water table base-level fluctuations correlating to major river system incisions. During periods of negligible regional incisions, cave levels may form. Despite the significant role dissolution plays in karstic genesis, physical erosional processes can enhance the formation of these karst systems and should not be ignored. For example, the lowering of the water table within a cave can expose the cave to more vadose conditions - leading to a decrease in roof-supporting buoyancy and ultimately the catastrophic failure of conduit ceilings resulting in areas of cave collapse. Cave collapse is an important indicator of the past hydrogeological and geomorphological conditions of a karst system; however, the location and extent of cave collapse are not always easily identifiable. Identifying areas that have experienced cave collapse can help uncover key clues for dissecting regional geologic history in terms of delineating cave levels for estimating previous base-levels and for reconstructing the timing of river system incisions. Using a LiDAR-derived digital elevation model (DEM), this study improves on previously constructed 
models for the delineation of cave levels as well as explores a new methodology for isolating areas that have experienced cave collapse. For cave level delineation, a histogram generated from extracted cave entrance elevations is clustered into four distribution groups. Two separate methods of delineation are explored, one using visual breaks in the data and the other utilizing Jenks Natural Breaks. For isolating areas of cave collapse, a weighted overlay was constructed utilizing three parameters - slope, distance from caves, and distance from streams. A sensitivity analysis was conducted to determine the most effective weighted distribution, resulting in a distribution of $70 \%, 20 \%$ and $10 \%$ respectively. Visible correlations exist between areas with a high probability of past collapse and the contacts between cave levels, as well as with other karst features. This indicates that cave collapse may preferentially occur at the boundaries between cave levels. It is necessary to ground truth the results of the cave collapse probability map to further validate its accuracy, but this study indicates that the methodology may be effective especially as an initial indicator to determine applicable locations to carry out future studies to explore cave collapse such as isotopic cosmogenic analysis.

KEYWORDS: Karst; Cave Collapse; River Incision; Cave Levels; GIS; Hydrogeology 
ISOLATING LOCATIONS OF POTENTIAL EPISODES OF CAVE COLLAPSE AND THEIR RELATIONSHIP TO CAVE LEVEL DEVELOPMENT THROUGH MAJOR RIVER SYSTEM INCISIONS

ETHAN WILLIAM CONLEY

A Thesis Submitted in Partial Fulfillment of the Requirements for the Degree of MASTER OF SCIENCE Department of Geography, Geology, and the Environment ILLINOIS STATE UNIVERSITY 
(C) 2021 Ethan William Conley 
ISOLATING LOCATIONS OF POTENTIAL EPISODES OF CAVE COLLAPSE AND THEIR RELATIONSHIP TO CAVE LEVEL DEVELOPMENT THROUGH MAJOR RIVER SYSTEM INCISIONS

ETHAN WILLIAM CONLEY

COMMITTEE MEMBERS:

Eric Peterson, Chair

John Kostelnick

Toby Dogwiler 


\section{ACKNOWLEDGMENTS}

I would like to express my immense gratitude and thanks to my thesis committee members, especially Dr. Eric Peterson for serving as my thesis advisor. The incredible advice and unending patience and support he offered me, along with his willingness to engage with me on a personal level through our mutual interests made my experience at ISU treasured. Thank you to Dr. John Kostelnick for contributing to my project through his expertise in GIS and by allowing his students to explore topics they found personally interesting. I also want to express my great thanks to Dr. Toby Dogwiler for his contributions stemming from his expert knowledge of karst and the area around Carter Caves State Resort Park. Special thanks to Illinois State University's Department of Geography, Geology, and the Environment for the use of equipment, lab facilities and overall, for the excellent extended education I have received.

To Eli Schukow, I would not have made it through this experience without you. I look forward to our many future adventures! Kelsey, thank you for tolerating me during my most stressful times. Your support means nothing short of the world to me. To my sister Brenna, thanks for always being the smart sibling and inadvertently making me the student I am today by motivating me to best you. Although I will always try, we both know I will never succeed.

This thesis is dedicated to my parents who have given up so much for me to achieve at such high levels. Mom, your constant prayers, and love are felt every day and mean more than you will ever comprehend. Dad, your passion for geology was transferred to me at a young age whether we knew it at the time or not. Your inspiring intelligence and incredible achievements drive me every day to become even half as successful. I love you both!

E.W.C. 


\section{CONTENTS}

Page

ACKNOWLEDGMENTS

$\begin{array}{ll}\text { TABLES } & \text { iii }\end{array}$

FIGURES

CHAPTER I: INTRODUCTION 1

CHAPTER II: MATERIALS \& METHODS 28

$\begin{array}{ll}\text { Site Description } & 8\end{array}$

$\begin{array}{ll}\text { LiDAR Data } & 12\end{array}$

$\begin{array}{ll}\text { Cave Levels } & 12\end{array}$

Digitization \& Euclidean Distance $\quad 12$

Weighted Overlay 13

$\begin{array}{ll}\text { CHAPTER III: RESULTS \& DISCUSSION } & 18\end{array}$

Cave Elevations \& Level Designations $\quad 18$

$\begin{array}{ll}\text { Weighted Overlay } & 25\end{array}$

$\begin{array}{ll}\text { CHAPTER IV: CONCLUSIONS } & 37\end{array}$

$\begin{array}{ll}\text { REFERENCES } & 39\end{array}$ 


\section{TABLES}

Table

Page

1. Parameter values associated with the ranks of reclassified input layers

2. Outcome of sensitivity analysis 


\section{FIGURES}

Figure

1. Carter Caves State Resort Park (CCSRP) is in northeast Kentucky, USA 10

2. Distribution of the sandstone and limestone within CCSRP. 11

3. Reclassified slope layer with 1 being the lowest slope and 10 being the steepest slope 16

4. Comparison of LiDAR derived and 10-m derived cave entrance elevations 18

5. Example of how changing resolution can impact assigned cave entrance elevations $\quad 20$

6. Cave levels derived from 10-m DEM data and a Jenks Natural Breaks statistical

$\begin{array}{ll}\text { methodology } & 23\end{array}$

7. Histogram displaying frequency of cave opening elevations extracted from the LiDAR generated DEM

8. Sensitivity analysis results illustrating the cell counts for each resulting probability class, ranging from 1-10 with 1 being least likely and 10 being most likely

9. $70 \%$ slope, $20 \%$ caves, \& $10 \%$ streams weighted overlay displaying probabilities of past cave collapse in and around CCSRP

10. A view of the karst window located between the lower Horn Hollow entrance and upper Laurel Cave entrance outlined by the dashed brown line

11. A series of karst windows in the western reaches of CCSRP

12. Lithologic contact with probabilities $9 \& 10$ visible

13. Karst terraces situated between areas of high probability of collapse 


\section{CHAPTER I: INTRODUCTION}

Karst landscapes, in which dissolution of bedrock is the dominant geomorphic process, make up 10\%-20\% of Earth's land surfaces (Palmer, 1991) and supply between $20 \%-25 \%$ of the global population with drinking water (Ford and Williams, 2007). Dissolution dominates the genesis of karst systems, creating flow pathways, conduits, and caves (Dreybrodt and Gabrovsek, 2003; Jennings, 1985; Martin and Dean, 2001; Parise and Pascali, 2003; Siemers and Dreybrodt, 1998). Some features within karst systems can be influenced through regional scale events such as major river system incisions (Anthony \& Granger, 2007; Springer et al, 2015). River system incisions can control regional scale water table base-levels, influencing the levels at which caves develop in a karstic region. When base-level is static for an extended period, a cave level may form as a visual representation of that base-level elevation (Palmer, 2007).

Periods of static base-level create cave passages, which can be grouped together by elevations (Palmer, 2007). These different groupings are considered as cave levels (Palmer, 2007). Cave levels are important karst geomorphic features as they can provide evidence to both assist in deciphering the timing of cave system development and to improve upon genesis models for major river system incisions. Cave level boundaries are often defined by a change in predominate horizontal flow to vertical flow. This transition is created by an episodic lowering of the local base level that is a response to regional discharge changes. Cave level formation is also linked to the presence of fluvial terraces, or flat areas indicative of the long periods of static base-level (Worthington, 2005). Analysis of cave entrance elevations has been used to derive levels of caves (Peterson et al., 2011; Jacoby et al., 2013).

Despite the significant role dissolution plays in the initial genesis, physical erosional processes enhance the formation of these karst systems (Palmer, 1991) and should not be ignored 
(Aley, 1965; Bosch and White, 2007; Dogwiler and Wicks, 2004; Palmer, 1991; Sanders, 1981). River incisions can trigger physical alterations to karst systems, such as episodes of cave collapse (Hill and Polyak, 2014; Lollino et al., 2013) caused by a drop in water level resulting in a loss of roof supporting buoyancy (Girihagama et al., 2015). Cave collapse not only dramatically changes the landscape and creates new hydrological dynamics for the system, but also exposes the geological evidence necessary to identify cave levels.

Areas of cave collapse are not always easily identifiable. To better understand catastrophic rock failure and its impacts on karst systems, identifying locations where collapse has occurred is fundamental. Increasing the number of documented areas that have experienced cave collapse will also assist future studies in developing models of major river system incisions. Previous studies have linked the lowering of local and regional water table base levels to periods of rapid river incision (Anthony \& Granger, 2007; Springer et al., 2015). Cave level formation at Mammoth Cave (Kentucky), the longest known cave in the world, was closely controlled by the local history of fluvial entrenchment linked to rivers in the Interior Low Plateaus that are influenced by the Ohio River (Davies, 1960; Powell, 1970; White, 1988; Bocchini and Coltorti, 1990; Granger et al., 2001).

Other theories that are currently being explored state that the incision of the Ohio River (Woodside et al., 2015) and the Colorado River (Hill and Polyak, 2014) also influence areas of cave collapse. The lowering of local and regional base-level may initiate episodes of cave collapse. As the water table drops, a cave passage transitions to vadose conditions, creating a decrease in roof-supporting buoyancy (Girihagama et al., 2015). The significant loss in buoyancy that forces the cave passage ceiling upwards during a change in base-level causes the ceiling to fail and collapse entirely. Cave collapse not only creates significant visual surficial changes, but 
also can create blind valleys and ultimately expose the fluvial terraces associated with cave levels.

Blind valleys are important features when discussing areas that have experienced episodes of karstic collapse. Blind valleys, also known as karst windows, are areas of collapse that allow entry into the underground environment (Sauro, 2019). Karst windows can vary in size from a few meters to hundreds of meters (Sauro, 2019). Karst windows lack the presence of standing water as any water that enters the depression is pirated into the subsurface. A key aspect in the identification of blind valleys is the lack of surficial drainage patterns exiting the depression. Typically, with topographic depressions there are visible fluvial channels from which the water exits the depression, but with karst windows these are not present. The lack of drainage channels can be visually observed utilizing high resolution aerial imagery. Blind valleys are important in the context of this study as they serve as a benchmark for previously identified areas of collapse, providing context to the results.

Exposed streams within blind valleys exhibit steep-sided profiles. Stream profile shape offers insight into where along a karst stream profile collapse has previously occurred (White and White, 1983; Woodside et al., 2015). Locations along the stream profile that exhibit a "V" shaped channel (in cross-section view) and lack near vertical walls are indicative of natural downcutting processes. Steam profile cross-sections with vertical bedrock walls are indicative of karst collapse. For these areas to be the result of natural downcutting, the rate of incision would have had to be extremely rapid, and similar profile shapes would be expected throughout the entirety of the system. Areas with vertical bedrock walls are additional support for likely areas of collapse with the presence of large, angular sediments, but again the presence of these sediments is largely time dependent. This idea can be transferred to thinking strictly about slope in karst 
areas. From this idea, it is reasonable to suggest that in karstic regions, areas of collapse will have steeper slopes than areas that have not experienced collapse.

Cosmogenic analysis of bedrock and cave sediment is an accurate methodology to compliment studies in river system incision history (Granger et al., 1997; Springer et al., 1997); however, the utilization of these analyses is expensive. If cosmogenic isotope analysis is to be employed by a study exploring areas of potential cave collapse and differing cave levels, it would be extremely useful to have a pre-determined, well-supported location as to where to collect samples for such a study. As geospatial tools have improved and the resolution of geospatial data have increased, spatial analyses may be able to provide accurate preliminary assessments for areas that have experienced past episodes of cave collapse. Identified areas can be ground-truthed with aforementioned techniques.

Prior to utilizing geospatial data, it is important to understand the role that spatial resolution with play in the analysis. Spatial resolution requirements of geospatial data differ depending on the application, including characterizing complex topographic environments. Several studies have explored the impact that horizontal resolution has on the effectiveness of analysis in different geographic and geologic settings (Hammer et al., 1995; Zhang et al., 1999; Peterson et al., 2011; Jacoby et al., 2013; Ferro-Famil \& Pottier, 2016). Low resolution spatial data are well adapted to characterizing or analyzing phenomena at a large scale as they operate in large spatial coverage modes (Ferro-Famil \& Pottier, 2016). However, these lower resolutions are not always as well suited for small-area environments and cannot distinguish minute characteristic details required to fully understand and describe the study area (Ferro-Famil \& Pottier, 2016). Other studies have shown that a finer resolution does not necessarily result in 
higher accuracy, as displayed by the Mahalingam et al. (2016) exploration of resolution influence on landslide predictive accuracy for landslide susceptibility mapping.

An unpublished database compiled by the Wittenberg University Speleological Society (WUSS) contains the geographic locations of cave openings in and around Carter Caves State Resort Park (CCSRP). In 2011, Peterson et al. (2011) began efforts to identify and delineate cave levels within the park by pairing the cave data provided in the WUSS database with elevations utilizing a digital elevation model (DEM) with 30-meter by 30-meter horizontal resolution. This study resulted in a preliminary delineation of four cave levels within CCSRP. Due to the regional similarities, the results from CCSRP were compared to those of similar studies at Mammoth Cave and the Cumberland Plateau (Anthony and Granger, 2004; Granger et al., 2001), and correlations were found.

Peterson et al. (2011) utilized data with a low horizontal resolution of 30-meter by $30-$ meter to classify a study site area of approximately $106 \mathrm{~km}^{2}$. With access to better resolution data, Jacoby et al. (2013) utilized the methods provided by Harlan (2009) to perform cave level identification at CCSRP employing a DEM with 10-meter by 10-meter horizontal resolution and a $0.363 \pm$ vertical accuracy. The hypothesis of Jacoby et al. (2013) was that improving the horizontal resolution of the DEMs would provide a more accurate distinction between cave level elevations. The refinement of the horizontal resolution resulted in the introduction of a possible fifth cave level within CCSRP. As high-resolution spatial data such as LiDAR data continues to become more widely available, the question arises of the effectiveness of a lower resolution such as 10-meter by 10 -meter. This study further explores the comparisons between different tiers of resolution by once again duplicating the methods of Peterson et al. (2011) and Jacoby et al. 
(2013), except this time utilizing LiDAR data with 0.68 -meter horizontal resolution and a $15 \pm$ centimeter vertical accuracy (KGS, 2016).

LiDAR derived elevation data are a great option for improving upon the accuracy of previous studies. LiDAR elevation data are different in that it is not created by resampling a lower resolution dataset. For example, some $10 \mathrm{~m} \times 10 \mathrm{~m}$ elevation datasets are the result of resampling a $30 \mathrm{~m} \times 30 \mathrm{~m}$ elevation dataset - meaning that the newly resampled $10 \mathrm{~m} \times 10 \mathrm{~m}$ dataset has the elevation source data of the $30 \mathrm{~m} \times 30 \mathrm{~m}$ dataset but has a higher spatial resolution. LiDAR data utilize lasers to measure the elevation of the ground, so the elevation data not only have a high spatial resolution, but the elevation data itself have also high resolution. Another reason why LiDAR data can be a better option is its ability to provide multiple returns from the same laser pulse. Multiple returns allow for the user to distinguish the bare ground terrain from surficial features such as dense tree canopies. This helps ensure that the collected elevation data are actually the ground surface and not the elevation of the tree canopy. LiDAR elevations could also prove to be more accurate than elevations collected using a GPS receiver. The precision and accuracy of data collected with GPS receivers decreases when used in forested landscapes (Deckert and Bolstad, 1996; Naesset and Jonmeister, 2002; Rodriquez-Perez et al. 2006, 2007; Danskin et al., 2009). GPS uses microwave signals - dense vegetation and topography can interfere with the satellite microwave signals, negatively impacting the vertical accuracy (Veal et al., 2001). LiDAR elevations are largely unaffected by dense vegetation and topographic features; so, LiDAR elevations in this type of geographic area may prove more accurate.

Theoretically, the use of LiDAR data should improve results and expand the utility of geospatial analysis within complex systems such as karst. However, LiDAR is not always accessible; so, determinations will also be made on whether it is necessary to obtain LiDAR data, 
or if a lower resolution such as $10 \mathrm{~m} \times 10 \mathrm{~m}$ would suffice. We hypothesize that an increase in DEM resolution will improve the accuracy of cave level delineation.

Given an increased understanding of the spatial resolution utilized in this project, this study also aims to isolate locations with the highest probabilities of past cave collapse episodes. To do this, a weighted overlay operation utilizing slope percentage and the geographic locations of both cave entrances and streams is carried out in and around the Carter Caves State Resort Park boundary. We hypothesize that the likelihood for cave collapse will decrease as the distance away from cave entrances and streambeds increases. We also hypothesize that based on the known locations of the previously derived cave levels, areas of high probability of collapse may correlate to the contacts between cave levels. 


\section{CHAPTER II: MATERIALS \& METHODS}

\section{Site Description}

Carter Caves State Resort Park (CCSRP), located in Carter County, KY consists of approximately $106 \mathrm{~km}^{2}$ of deeply incised valleys, characteristic of the Cumberland Plateau (Engel and Engel, 2009) (Figure 1). Located within the northwest-central portion of Carter County, Kentucky, elevations range from 344m at the highest point to about $200 \mathrm{~m}$ at base-level. Approximately one-quarter of Carter County consists of karst landscapes, and there are over 200 named pits and caves within a $40 \mathrm{~km}$ radius of CCSRP (Angel and Peterson, 2015; Engel and Engel, 2009; Jacoby et al., 2011a; Jacoby et al., 2011b; Jacoby et al., 2013; McGrain, 1966; Peterson et al., 2011).

The bedrock units in the study area are Mississippian and Pennsylvanian in age. A sequence of carbonates with a maximum thickness of about $25 \mathrm{~m}$ are bounded stratigraphically by siliciclastic units (Engel and Engel, 2009) (Figure 2). The oldest unit exposed near CCSRP is the Mississippian-aged Borden Formation. The Borden Formation is composed of shale, which prevents further downcutting in the region. The Borden also acts as the bed of some reaches in Tygarts Creek, which runs through CCSRP (Ochsenbein, 1974; Engel \& Engel, 2009). Above the Borden Formation, the Mississippian-aged Newman Formation is the primary cave forming unit within CCSRP (Ochsenbein, 1974; Engel \& Engel, 2009). It is approximately $60 \mathrm{~m}$ thick and is heavily jointed, allowing for aggressive recharge events to further drive dissolution of the carbonate bedrock (McGrain, 1966; Engel \& Engel, 2009). With a regional dip of approximately $2^{0}$ to the east-southeast, multiple levels of caves have developed in the nearly horizontal carbonate units; an offset of at least 5 m separates the levels (Pfeffer et al., 1981; Hobbs III \& Pender, 1985; Harlan, 2009). Acting as a resistive cap in and around CCSRP, the Pennsylvanian- 
aged Pennington Formation is a $100 \mathrm{~m}$ thick sandstone unit overlying the Newman Formation (Ochsenbein, 1974; Engel \& Engel, 2009). The contact between the Newman Formation and the Pennington Formation occurs uniformly at 273 m (Jacoby et al., 2013). Readers are directed to Engel and Engel (2009) and Ochsenbein (1974) for further detailed descriptions of the stratigraphy, regional structure, and topography of CCSRP. Wittenberg University Speleological Society (WUSS) has compiled an unpublished database containing the geographic locations of cave openings (Figure 2).

Multiple karst characteristics that are directly tied to this study have been previously identified at CCSRP and are important to highlight for future context. Francis et al. (2018) determined that limestone stream segments have a greater steepness index (SI), the slope of the transformed stream profiles, than sandstone stream segments. The authors further noted a distinct change in slope or SI values at the contact between the sandstone and limestone units, with stream segments within limestone having steeper slopes. Similarly, Thaler and Covington (2016) identified higher steepness values for limestones when capped by a sandstone within the Buffalo National River Basin in Arkansas, USA. Karst windows, or blind valleys, are also present within CCSRP. Several studies have identified the dry surface channel associated with the Horn Hollow fluvial karst system as being a blind valley. Lying between the entrances of Horn Hollow Cave and Laurel Cave, the valley is perched $14 \mathrm{~m}$ above Cave Branch Creek (McGrain, 1966; Woodside et al., 2015). The stretch between the entrances of Horn Hollow Cave and Laurel Cave acts as the surface and subsurface drainage system associated with Horn Hollow Creek (Dogwiler \& Wicks, 2004; Angel \& Peterson, 2015). 


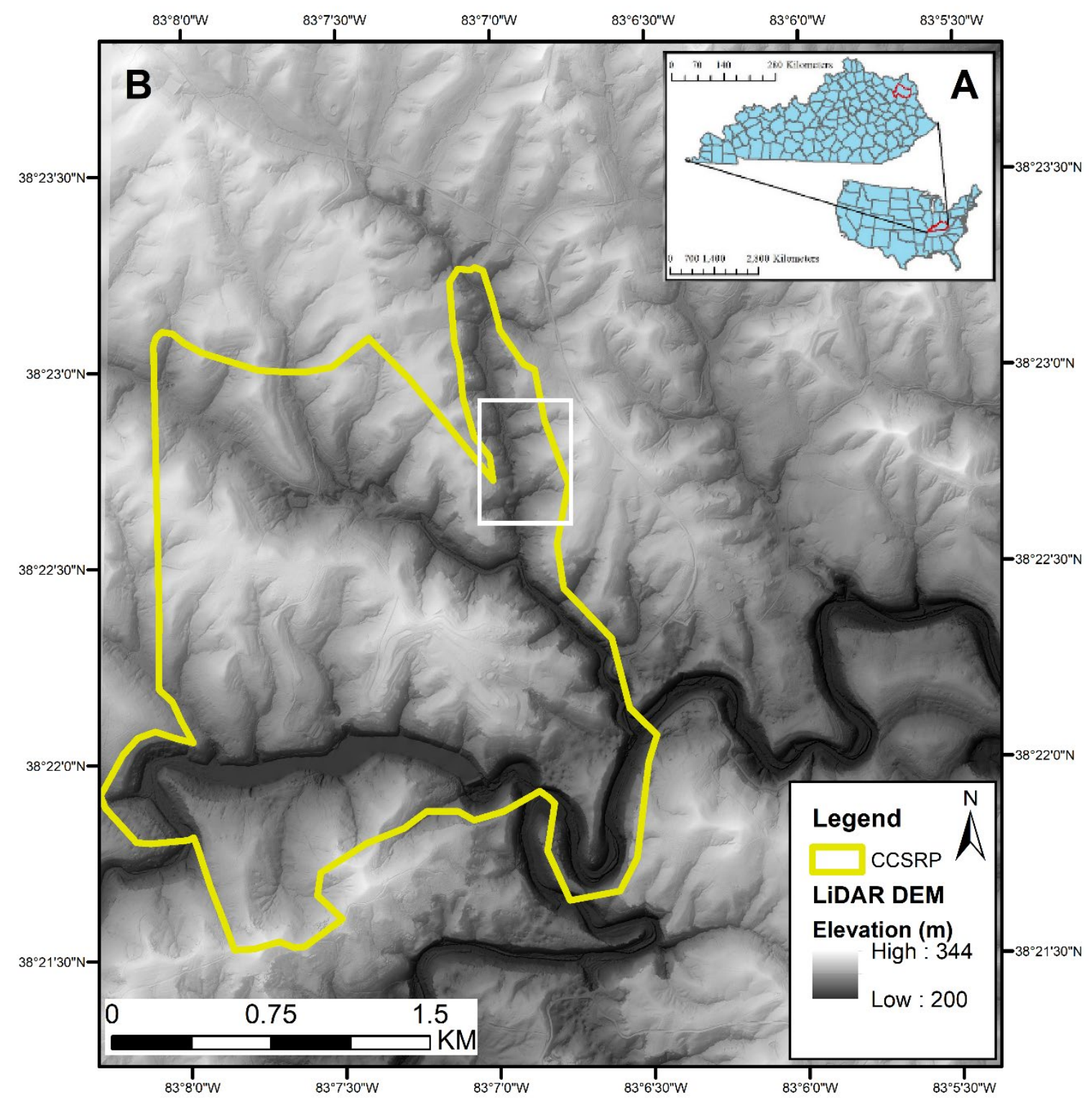

Figure 1: A) Carter Caves State Resort Park (CCSRP) is in northeast Kentucky, USA. B) CCSRP's extent is indicated by the yellow outline. The white box outlines the lower portion of Horn Hollow. 


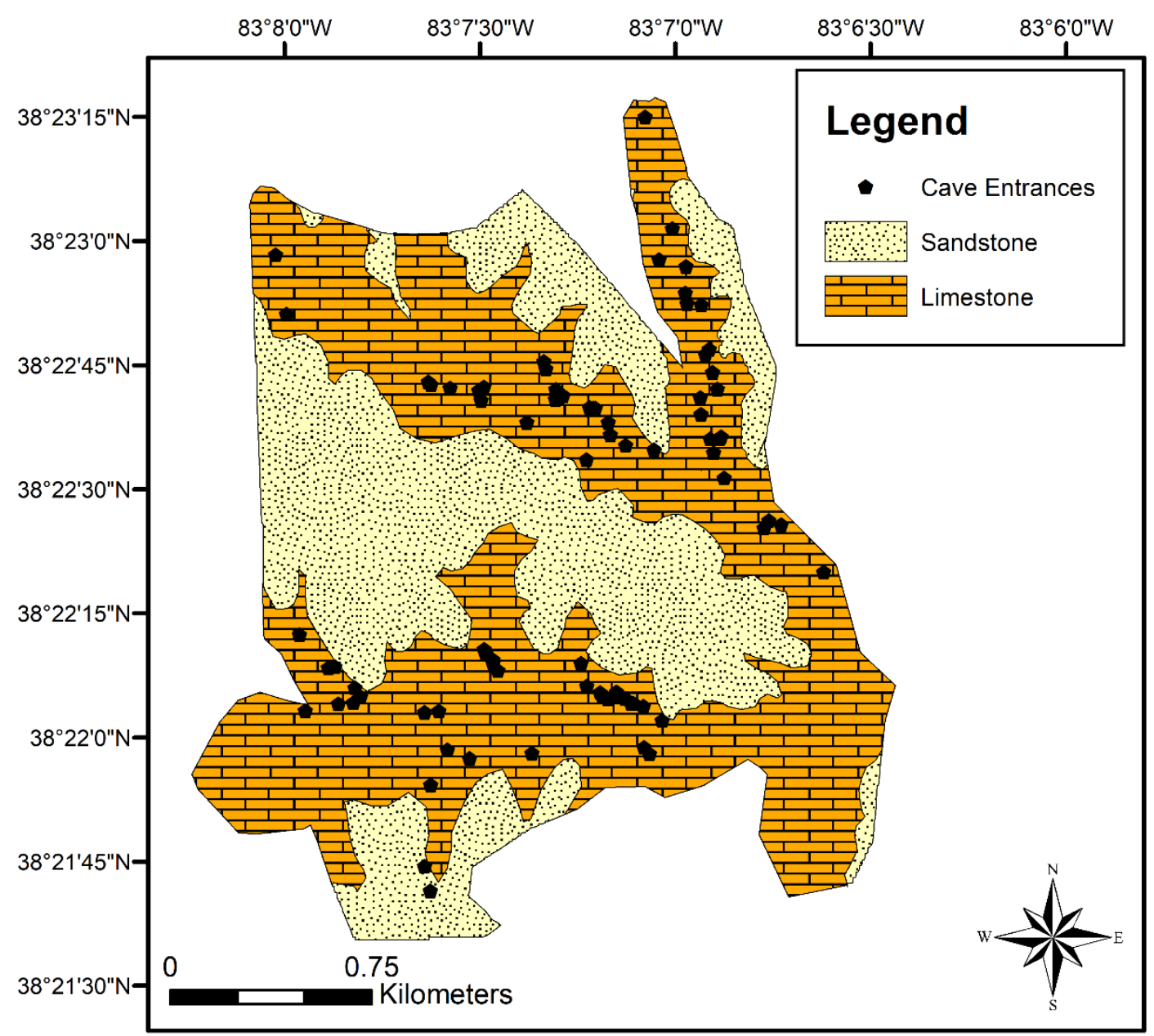

Figure 2: Distribution of the sandstone and limestone within CCSRP. Locations of cave openings also identified. 


\section{LiDAR Data}

Twelve LAZ files (compressed point cloud data) were download from KGS Geo Portal (University of Kentucky - https://kgs.uky.edu/kgsmap/KGSGeoPortal/KGSGeoPortal.asp). The LiDAR data have an average of $0.68 \mathrm{~m}$ or better horizontal resolution and vertical accuracy of 15.0 centimeters (KGS, 2016). LAZ files are not compatible in ArcGIS, so the files were uncompressed into LAS files (LASzip Version 3.4.3.). Once converted, a LAS dataset was created, and all LAS files were imported into the data set. Next, a point file information was generated from the LAS files. Once created, calculation of the mean point spacing was completed from statistics in the attribute table. This mean point spacing was used to create a new terrain from the multipoint data. The surfaces were converted to a raster $(0.68 \mathrm{~m}$ horizontal resolution) to allow for spatial analyses using the elevation data present in the layer.

\section{Cave Levels}

Using the cave opening dataset (WUSS), the Latitude and Longitude coordinates of the individual caves were plotted in the GIS. Following the plotting of caves, elevations from the LiDAR DEM were extracted from each cell containing a cave opening. A histogram of the cave elevations was generated; cave levels were delineated both visually and by Jenks Natural Breaks method (Slocum et al., 2009) to explore which methodology is more accurate.

\section{Digitization and Euclidean Distance}

A stream network was derived using the generated LiDAR raster by computing both flow direction and flow accumulation. This method was chosen over other options such as using previously derived stream networks like those provided by the USGS' National Hydrography Dataset because it was imperative that the resulting stream network aligned with our LiDAR 
DEM. Prior to derivation of both flow direction and flow accumulation, sinks were filled. The decision to fill sinks becomes a bit more complicated in karst systems due to the presence of natural pits and depressions in the form of sinkholes, or other collapse features. Filling sinks in a karst system assumes that all depressions are the result of an error (Jacoby et al., 2011). This study is not primarily focusing on these small pits, so the decision to fill sinks was solely based on creating a stream network that is representative of a surface drainage network (Jacoby et al., 2011). If sinks were not filled, the depressions evident in the DEM would "collect" water and eliminate further flow downstream (Jacoby et al., 2011). A well-defined stream network is essential for the methods of this study, which is a justifiable reason for filling sinks.

\section{Weighted Overlay}

To isolate areas within CCSRP that have likely experienced episodes of cave collapse, layers containing slope, distance from cave entrances, and distance to streams were utilized to

create a weighted overlay (Figure 3). To create the weighted overlay, the classes being used had to be assigned a percent weight defining the contribution of the class to the resulting layer (in this case past cave collapse probability). Weighted percentages are organized in the order of slope, distance from caves, and distance from streams (slope $\%$ cave $\% \_$stream $\%$ ).

To incorporate a cell's distance to the streams and to the nearest cave opening into a weighted overlay, the distance data need to be represented in an ordinal manner to allow GIS to recognize the significance of the features in relation to cave collapse probability. The best option in the case of these two features was to perform a Euclidean Distance operation, which assigns cells a numerical value based on distances to the nearest stream and cave entrance, respectively. A Euclidean Distance operation also allows for customization of output cell size, maintaining the original resolution of the data. The caves and streams Euclidean Distance layers were classified, 
with 1 assigned to cells furthest away from the nearest feature and 10 assigned to cells the closest to the nearest feature (Figures 3B and 3C) (Table 1). This is beneficial to the study as the likelihood for cave collapse may decrease as the distance away from cave entrances and streambeds increases. LiDAR derived slope was reclassified to an ordinal scale of 1-10, with 1 assigned to raster cells with the lowest slope and 10 assigned to the steepest slopes (Figure 3A) (Table 1). All processed and reclassified layers maintained the same cell size of the LiDAR data $(0.68 \mathrm{~m} \times 0.68 \mathrm{~m})$.

Slope was assigned the highest weight in all weighted distributions because collapse features, such as dolines, are characterized by vertical, steep-sided walls (Ford and Williams, 2007; Woodside et al., 2015; Sauro, 2019 ). Steep-sided walls are distinct to collapse dolines when compared to the gentle slopes of solution dolines that are formed through a gradual process of sagging or settling of overlying materials (Jennings, 1985).

Distance from known caves was assigned the second highest weight because generally when a cave collapses, another branch of that cave system would still exist.

Distance to streams was assigned the lowest weight because although water flow is crucial for the creation of caves, streams may form independent from cave genesis or form at a lower cave level altogether.

Based on data availability, the geographic extent for these three layers varied. As a result of the differences in processing extents, only probabilities two (2) through ten (10) of the final weighted overlay occurred within our study area. The areas with calculated values of probability one fell outside of the study area, essentially being eliminated when clipped down to the final extent. 
To determine the best weight combination for the three parameters, a sensitivity analysis was conducted. The sensitivity analysis examined 16 combinations of slope, distance to caves, and distance to streams to determine the importance of each parameter and to optimize an output that effectively portrays the significance of the individual parameters. Weighted percentage combinations ranged from $90 \% \_5 \% \_5 \%$ to $34 \% \_33 \% \_33 \%$ (Table 1). Once all weighted overlays were created with the varying percent weights (Table 1), cell counts for each resulting probability class (ranging from 1-10 with 1 being least likely and 10 being most likely) were compiled and graphed in excel. 
A.
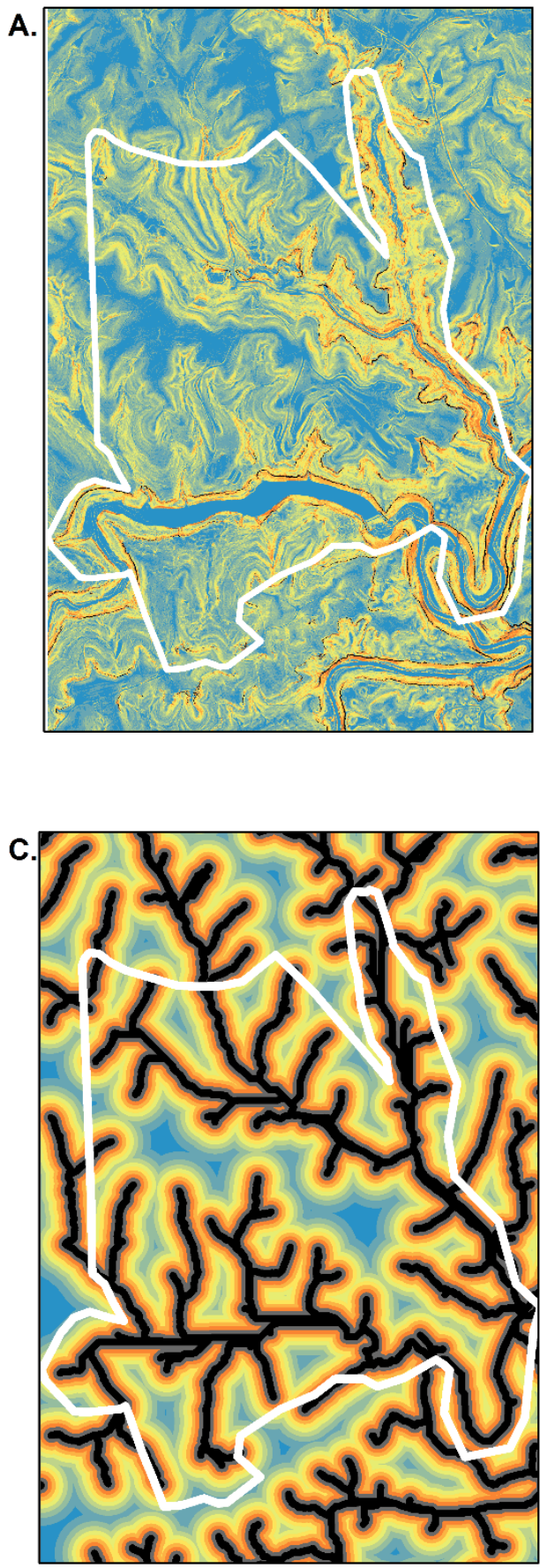

B.
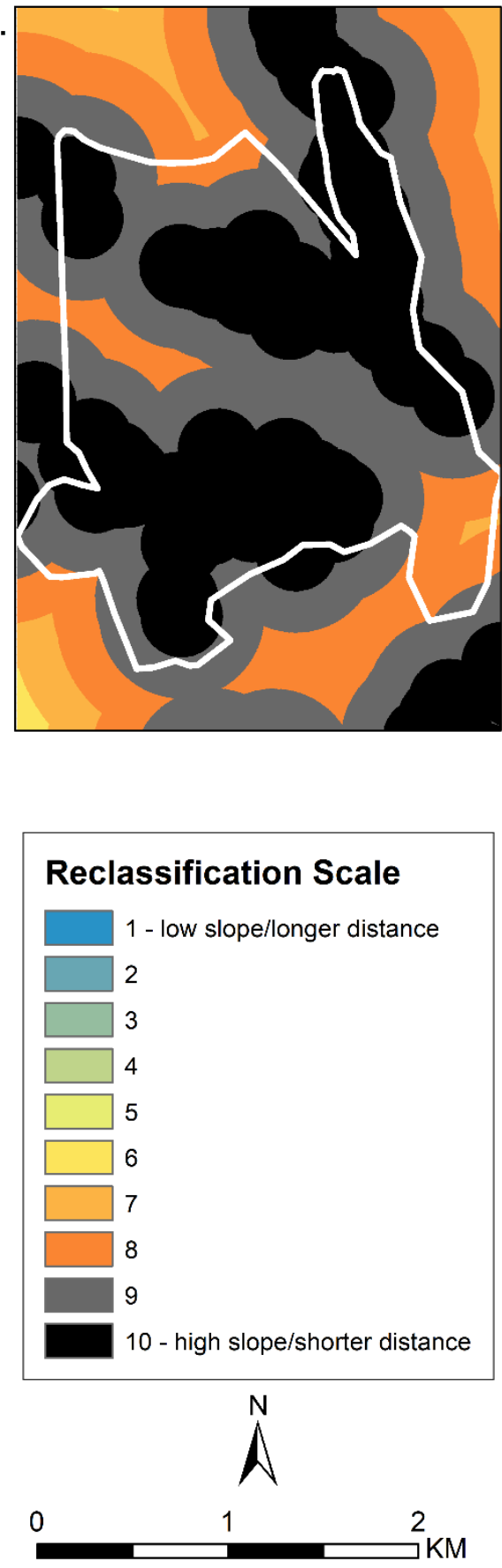

Figure 3: A) Reclassified slope layer with 1 being the lowest slope and 10 being the steepest slope B) Reclassified cave layer with 1 being the farthest from cave entrance and 10 being the closest to cave entrance C) Reclassified streams layer with 1 being the farthest from stream and 10 being the closest to stream. For all three of these layers, values of 1 carry the least weight and values of 10 carry the most weight for weighted overlay analysis. 
Table 1: Parameter values associated with the ranks of reclassified input layers.

\begin{tabular}{|c|c|c|c|}
\hline Rank & \multicolumn{3}{|c|}{ Parameter } \\
\hline & $\begin{array}{c}\text { Distance to Stream } \\
(\mathrm{m})\end{array}$ & $\begin{array}{c}\text { Distance to Cave } \\
\text { Opening }(\mathrm{m})\end{array}$ & Slope (\%) \\
\hline 1 & $1112-727$ & $2841-2395$ & $5.1-0$ \\
\hline 2 & $727-600$ & $2395-2050$ & $9.5-5.1$ \\
\hline 3 & $600-512$ & $2050-1727$ & $14.0-9.5$ \\
\hline 4 & $512-438$ & $1727-1437$ & $18.4-14.0$ \\
\hline 5 & $438-368$ & $1437-1170$ & $23.5-18.4$ \\
\hline 6 & $368-298$ & $1170-925$ & $29.7-23.5$ \\
\hline 7 & $298-223$ & $925-691$ & $37.5-29.7$ \\
\hline 8 & $223-149$ & $691-457$ & $48.5-37.5$ \\
\hline 9 & $149-70$ & $457-230$ & $63.5-48.5$ \\
\hline 10 & $70-0$ & $230-0$ & $87-63.5$ \\
\hline
\end{tabular}




\section{CHAPTER III: RESULTS \& DISCUSSION}

\section{Cave Elevations and Level Designations}

To determine how the extracted cave elevation data changed from the LiDAR DEM to the 10-m DEM, we took the LiDAR cave elevations and subtracted the 10-m cave elevations. We then calculated the average of those values which was $-0.73 \mathrm{~m}$ (Figure 4$)$. This tells us that on average, the 10-m cave elevations are slightly higher than the LiDAR cave elevations.

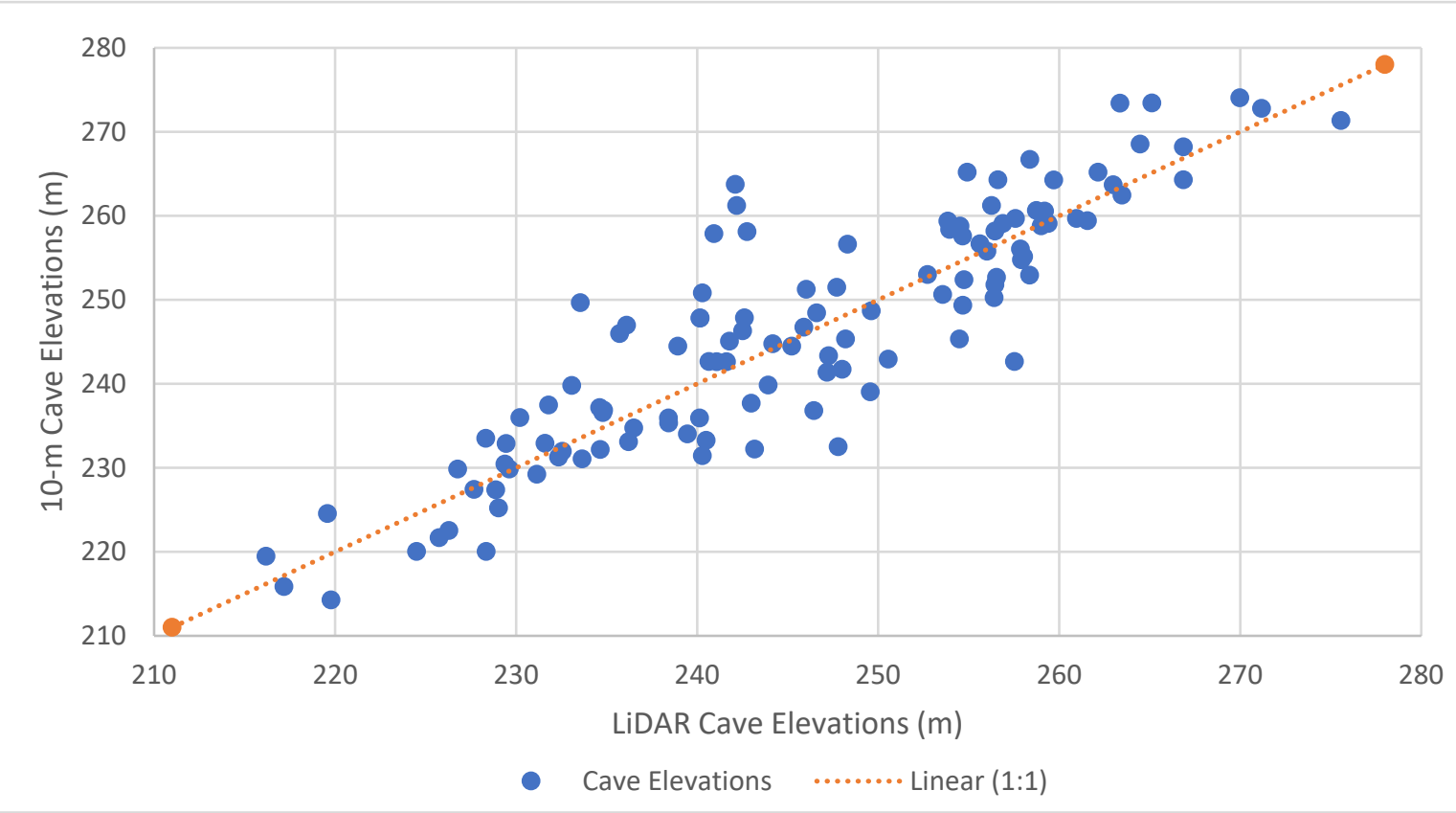

Figure 4: Comparison of LiDAR derived and 10-m derived cave entrance elevations (Jacoby et al., 2013). LiDAR cave elevations are on average $0.73 \mathrm{~m}$ lower than $10-\mathrm{m}$ derived caves. The orange dotted line represents the 1:1 line. 
Differences in spatial resolution can impact the assigned elevation value of a single point in a GIS. If the resolution of elevation data is low, the accuracy of the elevation assigned to a single point may also be lower because lower resolutions assign greater areas a single elevation value, leading to a more generalized result. If the resolution is higher, rather than clumping surrounding elevations to satisfy an average value, the differences in topography will be better delineated and represented. An example of this phenomenon can be observed in Figure 5. Figure 5A displays a theoretical area within a study site with differences in elevation indicated by contour lines and represents the use of lower resolution data. Figure 5B represents the same theoretical area but is representing the use of a higher resolution data. In Figure 5A, the cave, along with the entire extent of the cell, is represented with an elevation of $285 \mathrm{~m}$. It can be inferred through the presence of contour lines that the elevation of the cave is lower than that, but because of the low resolution, the assigned elevation of the cell result does not agree. With Figure 5B, the resolution has improved the accuracy significantly, and the cave has an improved elevation of $240 \mathrm{~m}$. These concepts apply to any example where an improvement in data resolution exists, whether from 30-m to 10-m or 10-m to LiDAR data. 


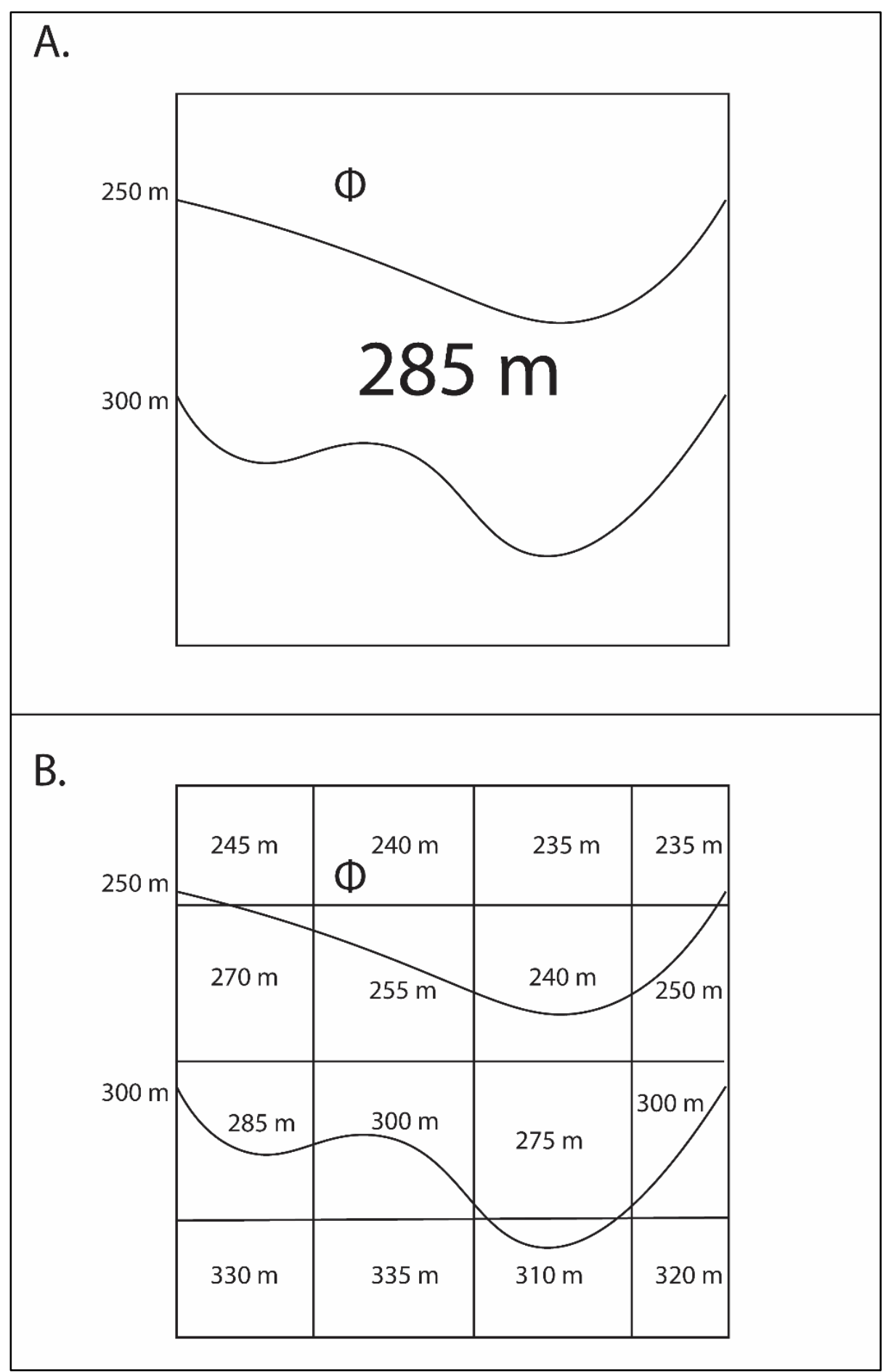

Figure 5: Example of how changing resolution can impact assigned cave entrance elevations. $\Phi$ symbol represents cave entrance location. A) Lower resolution data with an assigned cave elevation of $285 \mathrm{~m} \mathrm{~B}$ ) Higher resolution data with an assigned cave elevation of $240 \mathrm{~m}$ 
The location of higher elevation cave openings should be noted. The LiDAR-generated elevations have placed all but one cave within the limestone units, whereas previous reported elevations obtained using the lower resolution data sited several higher elevation cave openings within the extent of siliciclastic units. The LiDAR derived cave elevations average $0.73 \mathrm{~m}$ lower than the $10 \mathrm{~m}$ cave elevations. This results in some of the "siliciclastic" caves being shifted down into the proper carbonate lithology. Although cave formation is possible in siliciclastic units, it is not a common feature of the units in this area. This proved to be a source of error for both Peterson et al. (2011) and Jacoby et al. (2013). The resolution of the 10-m DEM made it appear as though six cave entrances were contained within the sandstone unit (Jacoby et al., 2013). For five of these caves, the higher resolution of the LiDAR data resolved this error. The contact between the Newman and Pennington Formations is characteristically very steep. Based on the reasoning expressed by Figure 5, the ability of LiDAR data to better delineate elevation differences within areas of steep slope explains this difference between the data sets.

Jacoby et al. (2013) identified four cave levels within CCSRP utilizing Jenks Natural breaks method with 10-m data (Figure 6A). The original study utilizing 30-m data (Peterson et al., 2011) also identified four cave levels. Regionally, similar cave level designations have been presented for the geologically similar Mammoth Caves system (Davis, 1930; Granger et al., 2001). Davis (1930) identified four distinct tiers of cave passages and explained their formation through the steady lowering of base-level., which has since been revised to forming from river system incisions (Sweeting 1950; Palmer, 1987; Anthony, 2005). 
With the extracted elevations, a histogram was created displaying the frequency of cave openings at each elevation (Figure 7). Using the 117 cave elevations derived from the LiDAR DEM data, four cave levels were identified. Two different derivations of cave levels were created with the LiDAR data. Utilizing visual breaks methodology in the histogram, breaks among layers occurred at $237 \mathrm{~m}, 245 \mathrm{~m}$, and $251 \mathrm{~m}$ (Figure 6B). The Jenks Natural Breaks methodology was chosen as the statistical method for delineation as its intended purpose is to identify real classes within the data by minimizing the difference between data values in the same class while maximizing the differences between classes (Slocum et al., 2009) (Figure 7). The Jenks Natural Breaks calculated layer breaks at $233 \mathrm{~m}, 244 \mathrm{~m}$, and $255 \mathrm{~m}$ (Figure 6C) (Figure 7).

Jacoby et al.'s (2013) cave levels generated using Jenks Natural Breaks were similar in thickness to the cave levels at Mammoth Caves and Cumberland Plateau, indicating validity to the results. Visually, the LiDAR cave levels which were derived using natural breaks were more similar to the cave levels produced by Jacoby et al. (2013) (6A \& 6C). This is especially the case when looking at just the thicknesses of each layer. For the above reasons, as well as for the sake of statistical consistency, the LiDAR cave levels derived using natural breaks are chosen over those derived using visual breaks. 

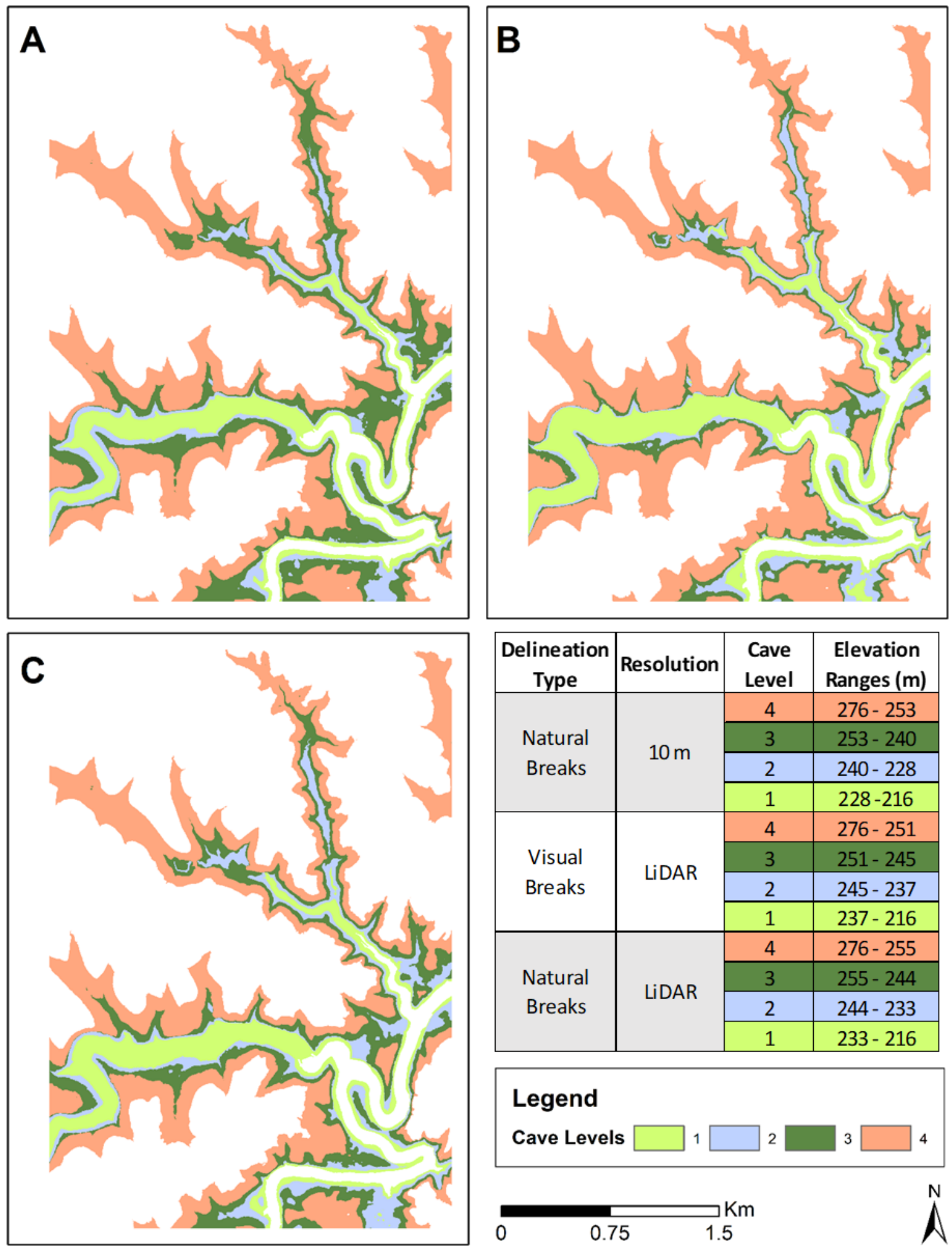

\begin{tabular}{|c|c|c|c|}
\hline $\begin{array}{c}\text { Delineation } \\
\text { Type }\end{array}$ & Resolution & $\begin{array}{l}\text { Cave } \\
\text { Level }\end{array}$ & $\begin{array}{l}\text { Elevation } \\
\text { Ranges (m) }\end{array}$ \\
\hline \multirow{4}{*}{$\begin{array}{l}\text { Natural } \\
\text { Breaks }\end{array}$} & \multirow{4}{*}{$10 \mathrm{~m}$} & 4 & $276-253$ \\
\hline & & 3 & $253-240$ \\
\hline & & 2 & $240-228$ \\
\hline & & 1 & $228-216$ \\
\hline \multirow{4}{*}{$\begin{array}{l}\text { Visual } \\
\text { Breaks }\end{array}$} & \multirow{4}{*}{ LiDAR } & 4 & $276-251$ \\
\hline & & 3 & $251-245$ \\
\hline & & 2 & $245-237$ \\
\hline & & 1 & $237-216$ \\
\hline \multirow{4}{*}{$\begin{array}{l}\text { Natural } \\
\text { Breaks }\end{array}$} & \multirow{4}{*}{ LiDAR } & 4 & $276-255$ \\
\hline & & 3 & $255-244$ \\
\hline & & 2 & $244-233$ \\
\hline & & 1 & $233-216$ \\
\hline
\end{tabular}
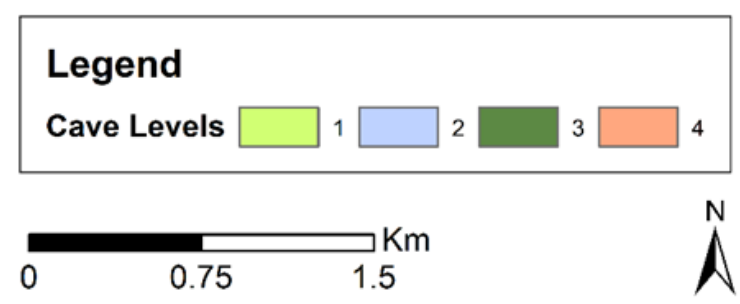

Figure 6: A) Cave levels derived from 10-m DEM data and a Jenks Natural Breaks statistical methodology (Jacoby et al., 2013) B) Cave levels derived using LiDAR DEM data and aa visual breaks methodology C) Cave levels derived using LiDAR DEM data and a Jenks Natural Breaks statistical methodology 


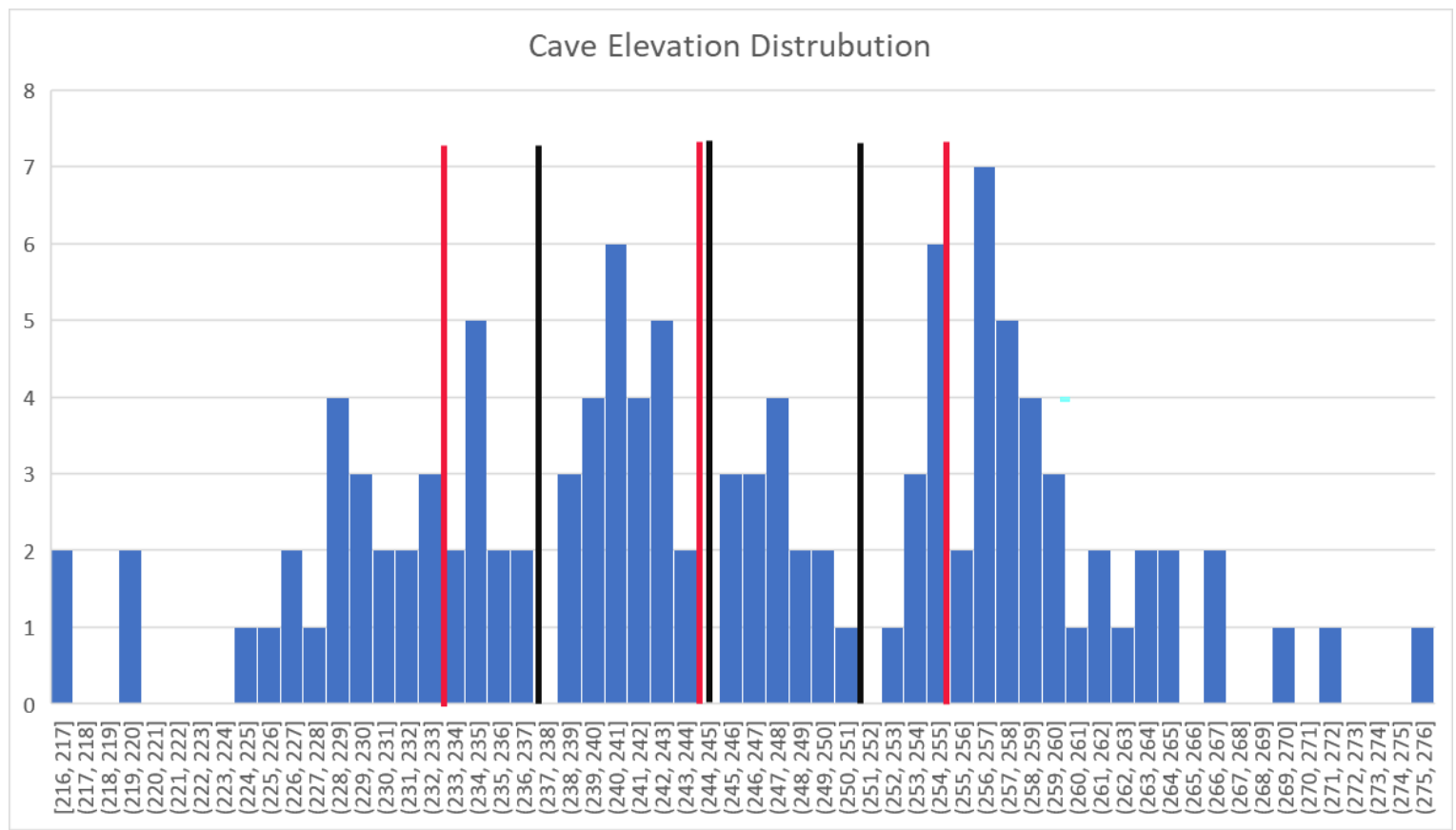

Figure 7: Histogram displaying frequency of cave opening elevations extracted from the LiDAR generated DEM. Red lines display the breaks derived from Jenks Natural Breaks method and Black lines display the visual breaks in the data. 


\section{Weighted Overlay}

This study sought to effectively differentiate areas that have experienced past collapse. Limiting the number of cells associated with the higher probabilities narrows the lens and makes for a more isolated output. Using the sensitivity analysis to optimize the results in this way, we aimed to achieve less than $2 \%$, but more than $1 \%$, of the total amount of cells to be included in probabilities nine and ten combined (Table 2) (Figure 8 ). The range of $1 \%$ to $2 \%$ of total cells in classes nine and ten was decided on after seeing the results. When results fell outside of that range, the probabilities were either too consistent with slope inputs or were more spatially generalized. Results that fell within the range were spatially consistent and higher probability cell count variations were minimal. Considerations were made to include probability eight, but after review of the output, these values were omitted due to an increased generalization of results. The upper threshold of $2 \%$ is exceeded when slope weight decreases to approximately $50 \%$ (Table 2). Once the slope weight drops below 50\%, higher probabilities become poorly delineated and were less defined. The lower threshold of $1 \%$ was exceeded when slope weight increased to approximately $90 \%$ (Table 2 ). The weighted combination of $90 \% \_5 \% \_5 \%$ met the criteria (between $1 \% \& 2 \%$ ) but was eliminated from consideration to prevent slope from skewing the results (Figure 8) (Table 2). When slope weight exceeds 90\%, the results were a function of slope and minimized the significance of the distances to the caves and the streams. Based on these limitations, a slope weight between $75 \%$ and $65 \%$ was considered optimal (Figure 8) (Table 2). For this range of weighted slope, outputs do not vary enough to raise concern on what weight was used, as long as it is within that range. The weighted distribution of $70 \% \_20 \% \_10 \%$ (Figure 9) was chosen as it allowed slope to be the driving factor of the output but provided optimal weight for both distance from cave openings and streams. 
Table 2: Outcome of sensitivity analysis

\begin{tabular}{|c|c|}
\hline $\begin{array}{c}\text { Weighted Distribution } \\
\text { (slope\%_cave\%_stream\%) }\end{array}$ & $\begin{array}{c}\text { Percentage of } \\
\text { probabilities } 9 \& 10 \text { out } \\
\text { of total cell count }\end{array}$ \\
\hline 90\%_5\%_5\% & $1.1 \%$ \\
\hline $80 \% \_15 \% \_5 \%$ & $1.0 \%$ \\
\hline $75 \% \_20 \% \_5 \%$ & $1.3 \%$ \\
\hline 70\%_15\%_15\% & $1.2 \%$ \\
\hline 70\%_20\%_10\% & $1.4 \%$ \\
\hline $70 \% \_25 \% \_5 \%$ & $1.5 \%$ \\
\hline 65\%_20\%_15\% & $1.5 \%$ \\
\hline $65 \% \_25 \% \_10 \%$ & $1.5 \%$ \\
\hline $60 \% \_40 \% \_0 \%$ & $1.6 \%$ \\
\hline 60\%_30\%_10\% & $1.6 \%$ \\
\hline $50 \% \_20 \% \_30 \%$ & $2.0 \%$ \\
\hline 50\%_30\%_20\% & $2.0 \%$ \\
\hline 45\%_35\%_20\% & $2.0 \%$ \\
\hline 34\%_33\%_33\% & $3.0 \%$ \\
\hline $30 \% \_50 \% \_20 \%$ & $4.6 \%$ \\
\hline 30\%_20\%_50\% & $4.1 \%$ \\
\hline
\end{tabular}




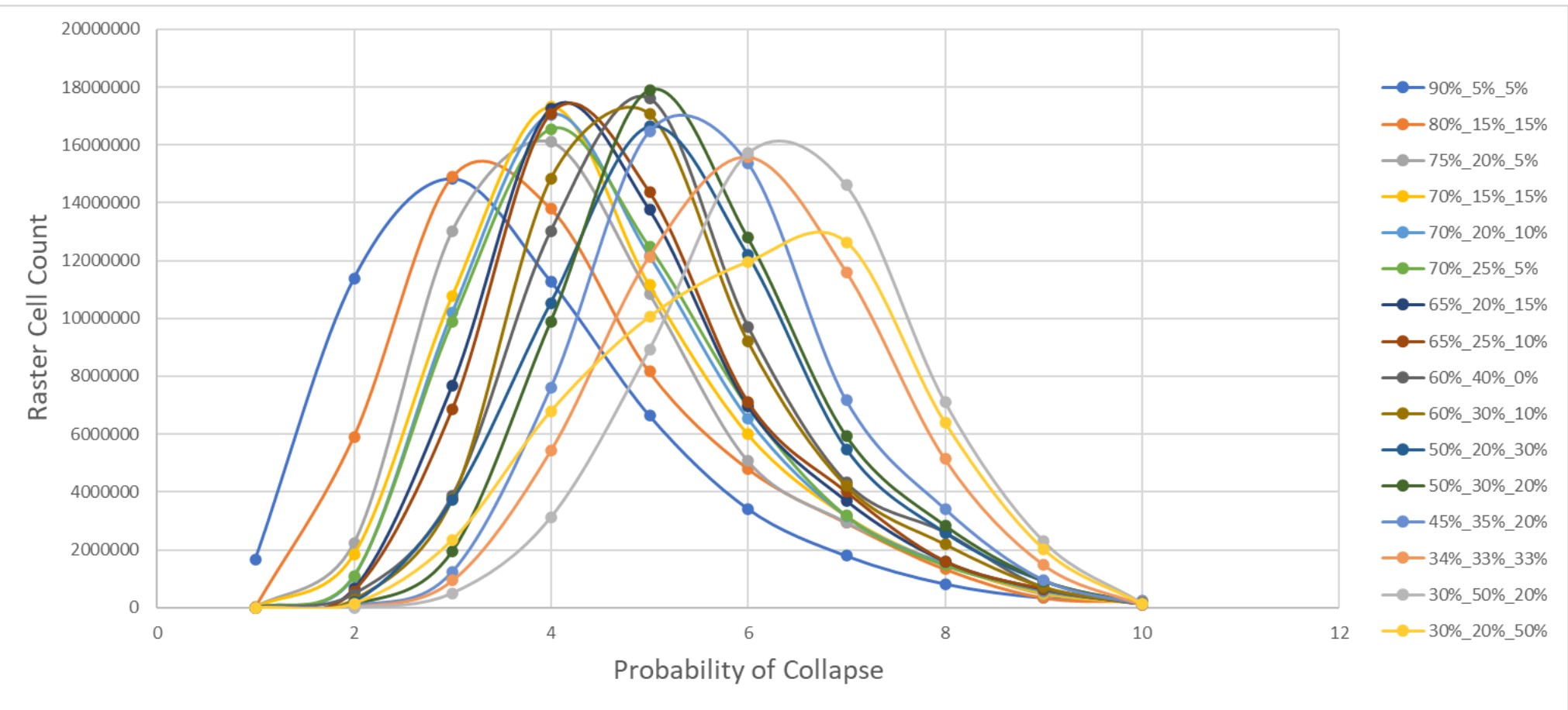

Figure 8: Sensitivity analysis results illustrating the cell counts for each resulting probability class, ranging from 1-10 with 1 being least likely and 10 being most likely. 


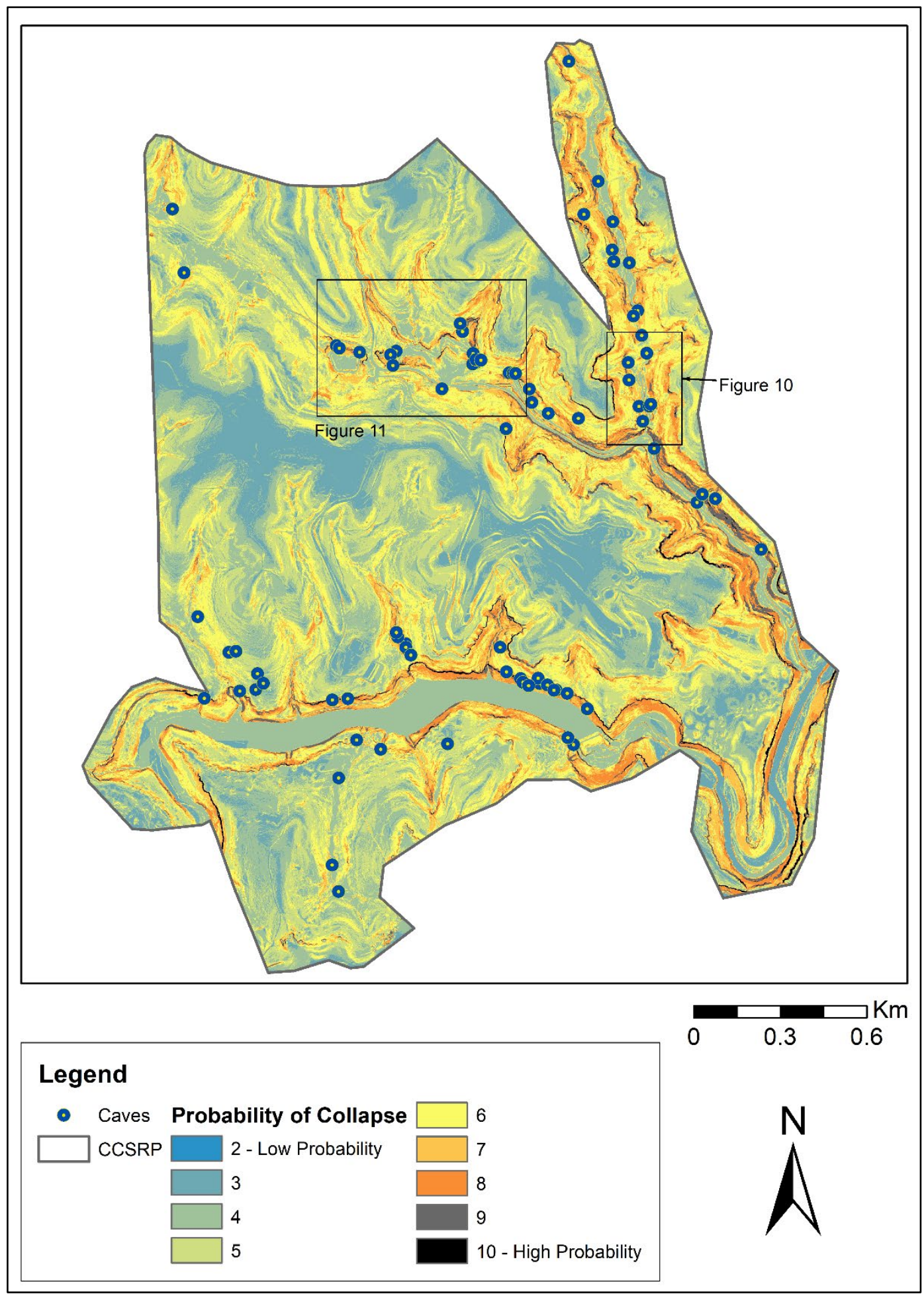

Figure 9: 70\% slope, 20\% caves, \& 10\% streams weighted overlay displaying probabilities of past cave collapse in and around CCSRP. Black boxes indicate extents for Figures 10 and 11. 
The weighted overlay (using $70 \% \_20 \% \_10 \%$ distribution) provides clear delineation between areas that have and do not have a high probability of past collapse (Figure 9). Several features indicate that this may be an effective methodology for cave collapse identification, including karst windows, contacts between lithologies, terraces between areas of high probability, and the visual correlation between high probabilities of collapse and contacts between known cave levels formulated previously in this study.

Karst windows have been previously identified at CCSRP (Woodside et al., 2015). A karst window is an area within cave systems that are exposed to light, typically because of cave passage collapse (Espinasa \& Borowsky, 2000). The first example of this is in the lower reaches of the Horn Hollow Cave System, connecting the downgradient entrance of Horn Hollow Cave to the upgradient entrance of Laurel Cave (Figure 10). The segment is a clear blind valley with steep walls and a lack of surficial drainage paths, indicating that water entering this valley must exit through an existing cave passage (Woodside et al., 2015). While the extent of the window was not defined with as much area defined by the maximum probability as other reaches, the extent of the window aligns with cells designated with the highest probability values. The second example in CCSRP consists of an interconnected series of karst windows (Figure 11). Figure 11 shows evidence of a potential flow path that enters and exits the subsurface several times. At each exit/entrance location, the area is marked by a high probability of past collapse. The predictability and pattern of these high probability cave entrances and exits attest to the linkage of the system. 


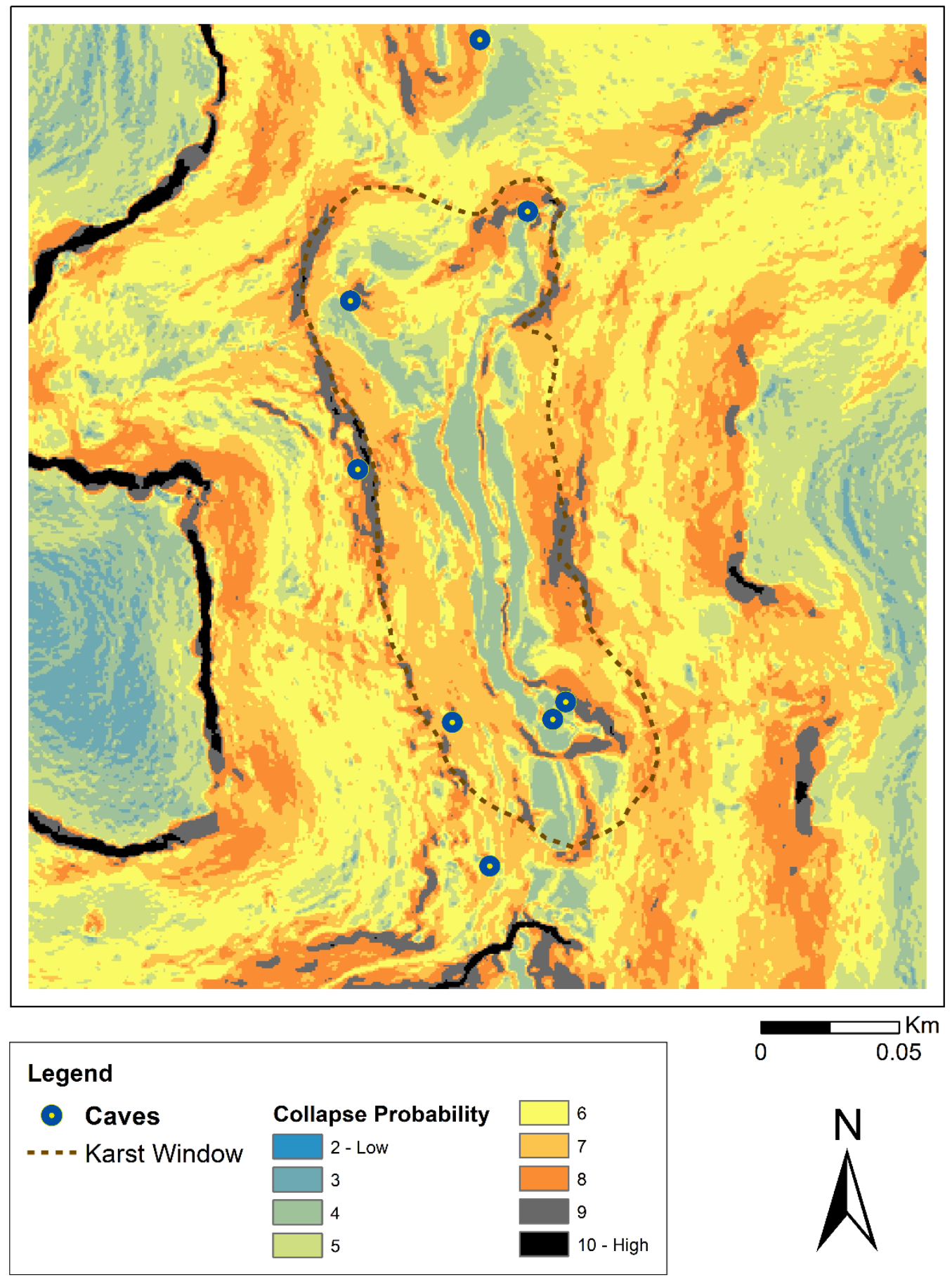

Figure 10: A view of the karst window located between the lower Horn Hollow entrance and upper Laurel Cave entrance outlined by the dashed brown line. The high probabilities within the karst window isolate steep faces that have been previously observed and deemed as cave collapse. 


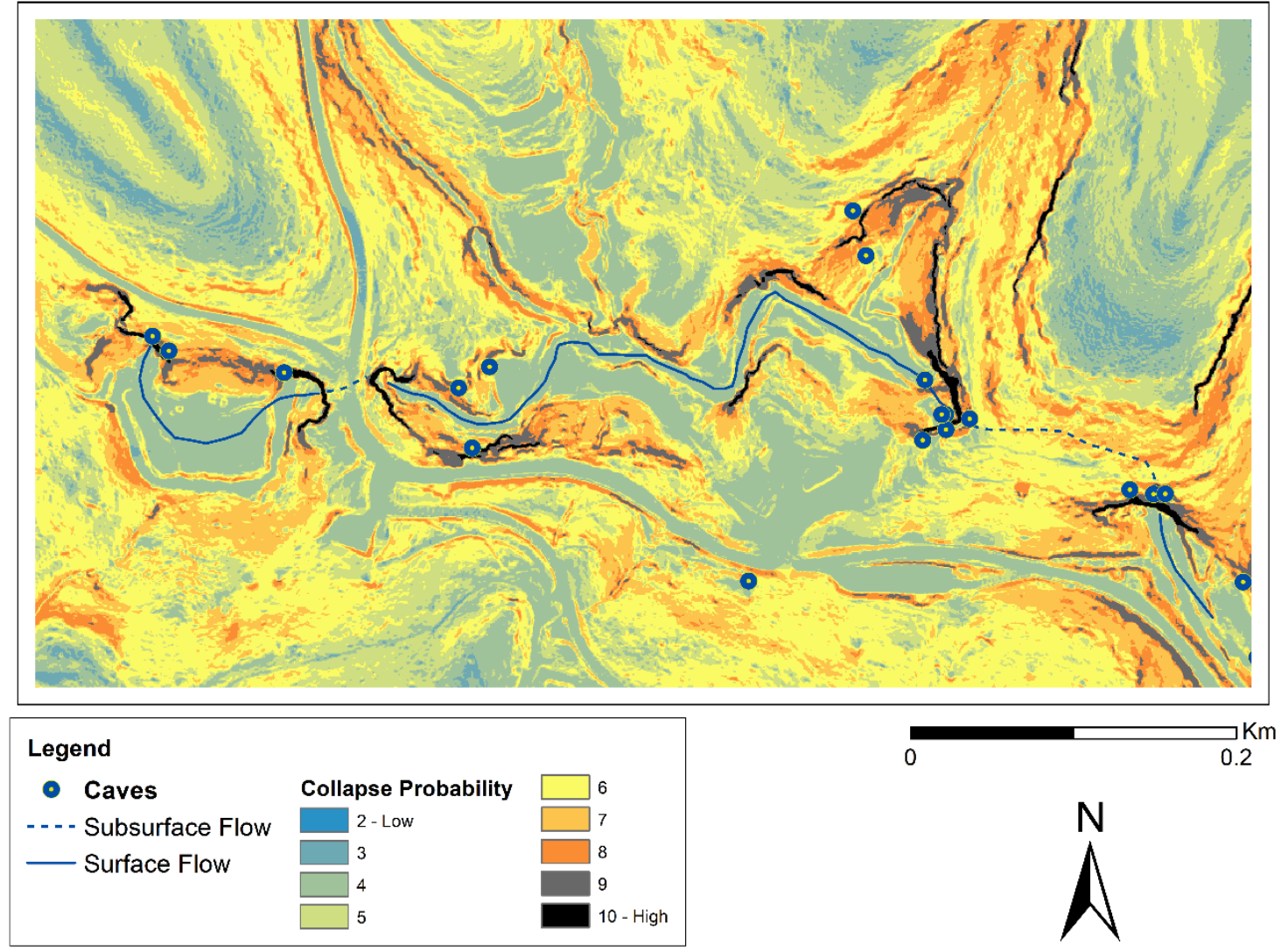

Figure 11: A series of karst windows in the western reaches of CCSRP. The blue line is displaying a theoretical path of interconnectivity. It is a possibility that this route was at one point completely entrained in the subsurface prior to a collapse of ceiling materials leaving behind these karst windows. 
Contacts between lithologies, especially in karst systems between a carbonate and noncarbonate, often yield identifiable features such as fluviokarst (Francis et al., 2018; Bočić, 2003; Jakucs, 1977). Fluviokarst landscapes consist of both fluvial and karst features (Francis et al., 2018; White and White, 1983). There may also be areas of high relief marking the contact. Areas of steep relief at contacts between the sandstone and limestone is evident throughout the CCSRP extent (Figure 12). Francis et al. (2018) aimed to determine and assess how erosional resistance of the sandstone and limestone at CCSRP relates to the overall development of the system. Within the system, sandstone stream reaches maintain greater equilibrium than limestone stream reaches (Francis et al., 2018). Limestone responds to both physical and chemical weathering whereas the sandstone will erode following physical weathering processes. This results in the water moving from the sandstone to the limestone maintaining its aggressiveness as it is yet to be neutralized by the non-soluble sandstone (Bogli, 1964). This aggressive water encourages dissolution and drives the limestone to a greater state of disequilibrium. This also leads to more subsurface piracy, further enhancing the equilibrium of the sandstone cap. The lithologic contact at CCSRP between the limestone and sandstone is marked by a steep contact. From the weighted overlay, the contact between the carbonate and siliciclastic units is well-defined (Figure 12). So, even if the contact is not marking an area of collapse in this case, it is still a useful result in accurately identifying the transition from a non-carbonate to carbonate lithology, which further supports the conclusions drawn by Francis et al. (2018). 


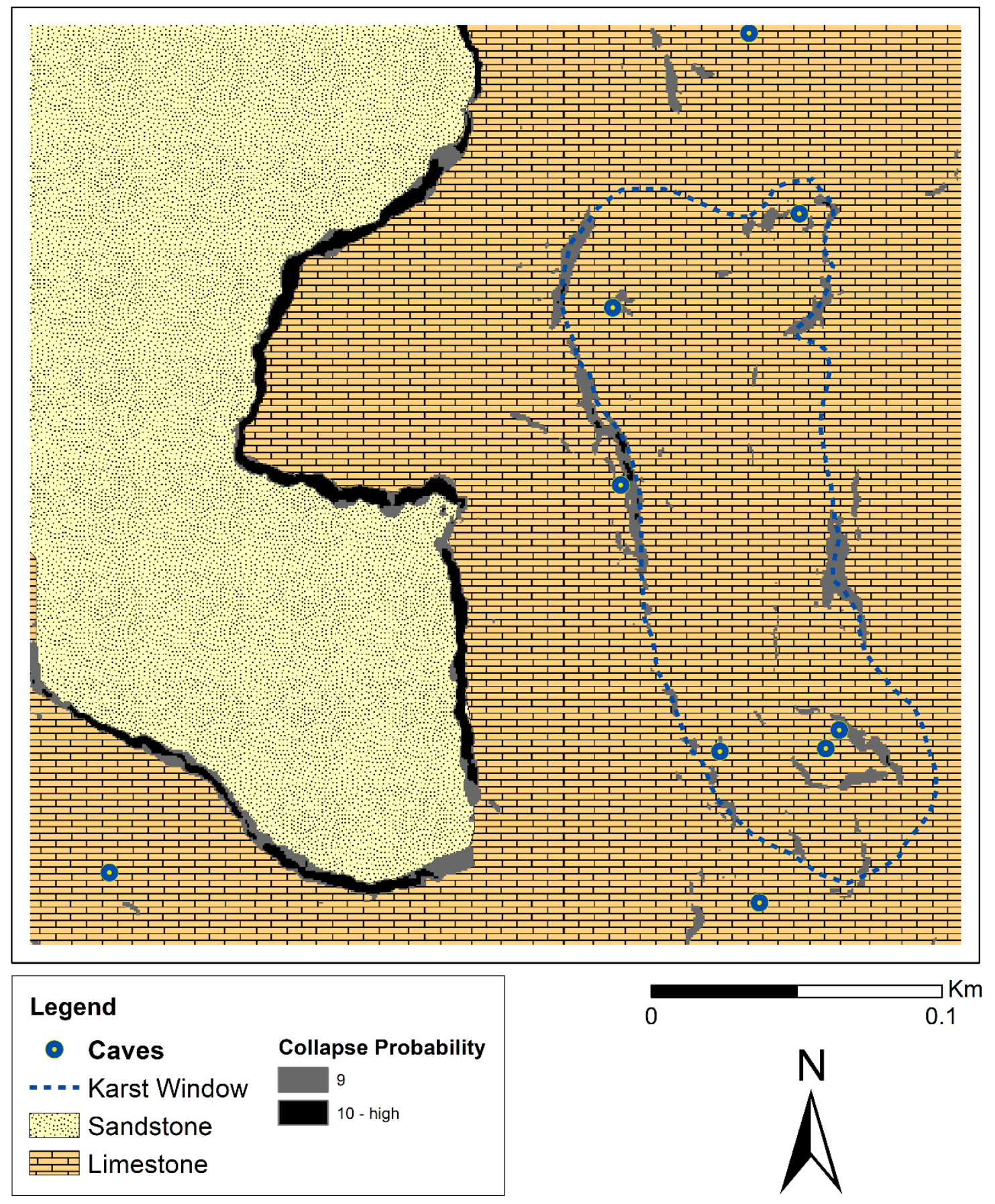

Figure 12: Lithologic contact with probabilities 9 \& 10 visible. Horn Hollow karst window (Fig. 8) is for spatial reference. 
Karst terraces are correlated with periods of a static regional base-level (Worthington, 2005). Many of the isolated areas of collapse are separated by what we interpret to be karst terraces. Based on the levels previously derived, the cave levels at CCSRP are directly tied to the karst terraces. Within Horn Hollow, several bands of cells classified as high probability of collapse were separated by areas of lower probability (Figure 13A). The high probabilities align with the boundaries of these cave levels suggesting that cave collapse may preferentially occur at the boundaries between cave levels (Figure 13B). It could additionally be interpreted as an indication for several episodes of collapse. As the water table drops, it may only expose a select number of cave levels to vadose conditions, leading to only those levels collapsing due to the loss in buoyancy. As the base-level changes over the course of time, this could repeat several times. This idea may apply both at CCSRP and in other systems with similar hydrogeological genesis. 

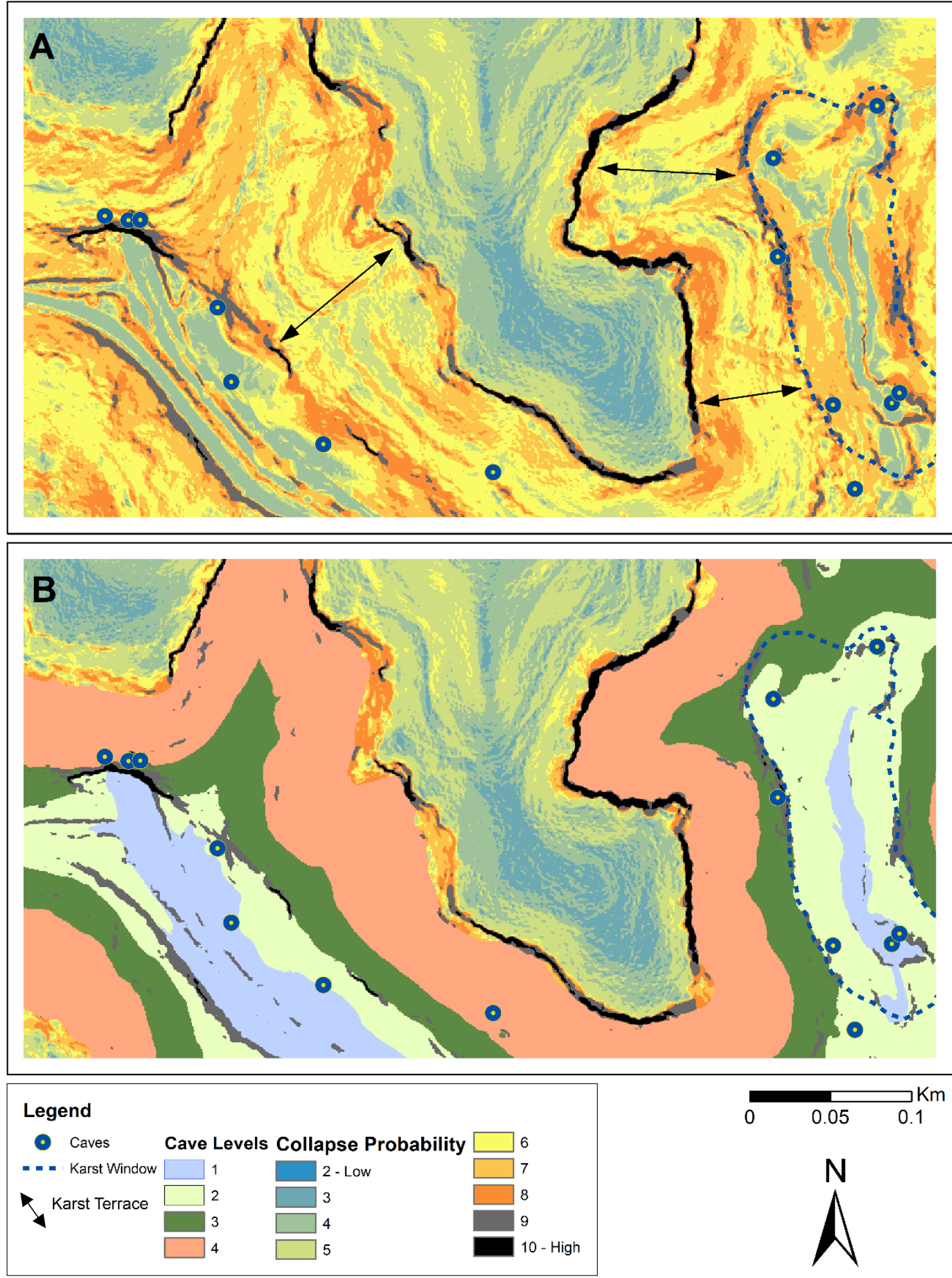

Figure 13: A) Karst terraces situated between areas of high probability of collapse indicated by arrows. B) Visible relationship between areas with high probability of collapse and the contacts between cave levels. 
This methodology is not constrained to a single study site. Any location that is characterized by karst topography and has sufficient data, including but not limited to cave entrance coordinates, can be analyzed for both cave level delineation and collapse identification. Based on the results of this paper, if there is geospatial data with resolutions of 10-m or better, cave levels and isolated areas of cave collapse can be identified. To further test the effectiveness of this methodology, the study could be duplicated at sites similar to CCSRP like Mammoth Caves or Cumberland Plateau. Results from future studies such as those could provide opportunities to revise and strengthen these methods. At that point, the study could be extended to explore regions that may differ slightly in characteristics, such as the history of incisions and collapse in the Grand Canyon. 


\section{CHAPTER IV: CONCLUSIONS}

Overall, the methodology used in this study is exploratory. The generated output isolated areas with a of high probability of past karstic collapse. Areas of high collapse probability are shown to have visible correlations with previously identified karst windows. These high probability areas also align with LiDAR generated cave-level boundaries and emphasize the dramatic contact between CCRSP's sandstone and limestone units. The correlation with cave level boundaries also provides further justification for cave levels derived from natural breaks being a more accurate methodology than doing so with visual breaks.

On the opposite side of the probability spectrum, low probabilities mark flat cave terraces and areas dominated by siliciclastic lithology. This evidence suggests that despite the experimental nature of the methods, they are promising for both the preliminary identification of collapsed areas and for other potential geospatial karstic research endeavors. These methods could also be tested at locations with similar karstic characteristics such as Mammoth Caves or Cumberland Plateau.

When deciding on an appropriate resolution for this methodology, there is a difference in results between the 10-m and LiDAR data, but that difference is not incredibly significant. If performing a study such as this, the decision to use either LiDAR data or 10m data may not matter as much as previously hypothesized. An improvement in results is probable with LiDAR data, but the study can still be completed with relatively similar results if $10 \mathrm{~m}$ resolution is all that is available.

For future studies, this methodology also provides much needed guidance for selecting sample locations for a more in depth and definite identification of cave collapse utilizing cosmogenic analysis. Cosmogenic analysis is an expensive methodology but could yield convincing evidence 
for areas of past collapse. This would also provide a necessary ground truthing of this methodology to ultimately determine its effectiveness. In addition to isotopic analysis, the results of this study may lend guidance to improving incision models for major river systems. The visible terraces and cave levels from this study can be used as a piece of a larger puzzle and could be duplicated in other karst regions to further progress hypotheses and interpretations for the genesis of these river systems. 


\section{REFERENCES}

Aley, T., 1965, Corrasional cave passage enlargement. Cave Notes, v. 7, no.1, p. 2-4.

Angel, J.C., Peterson, E.W., 2015, Nitrates in karst systems: comparing impacted systems to a relatively unimpacted system. Journal of Geography and Geology, v. 7, p. 65-76.

Anthony, D., and Granger, D., 2004, A Late Tertiary Origin for Multilevel Caves Along the Western Escarpment of the Cumberland Plateau, Tennessee and Kentucky, Journal of Cave and Karst Studies, v. 66.

Anthony, D.M., 2005, Multilevel Caves and Landscape Evolution, Encyclopedia of Caves, Elsevier, p. 397-400.

Anthony, D.M., Granger, D.E., 2007, An empirical stream power formulation for knickpoint retreat in Appalachian Plateau fluviokarst. Journal of Hydrology v. 343, p. 117-126.

Bocchini, A., and Coltorti, M., 1990, Il complesso carsico Grotta del Fiume-Grotta Grande del Vento e l'evoluzione geomorfologica della Gola di Frassassi, in Galdenzi, S., and Menechetti, M., eds., Il carsismo della Gola di Frasassi, Memori Instituto Italiano de Speleologia, v. 4, p. 155-180.

Bočić N., 2003, Relation between karst and fluviokarst relief on the Slunj Plateau (Croatia). Acta Carsologica, v. 32, p. 137-146.

Bogli, A. 1964, Mischungkorrosion, ein Beitrag zur Verkarstungsproblem: Erdkunde, v. 18, p. 83-92. 
Bosch, R.F., and White, W.B., 2007, Lithofacies and transport of clastic sediments in karstic aquifers: Studies of Cave Sediments: Physical and Chemical Records of Paleoclimate, p. 122.

Danskin, S.D., Bettinger, P., Jordan, T.R., and Cieszewski, C., 2009, A comparison of GPS performance in a southern hardwood forest: Exploring low-cost solutions for forestry applications: Southern Journal of Applied Forestry, v. 33, p. 9-16.

Davies, W.E. 1960. Origin of caves in folded limestone. National Speleological Society Bulletin 22: $5-18$.

Davis, W. M., 1930, Origin of limestone caverns, Geological Society of America Bulletin, v. 41, p. $475-628$.

Deckert, C.J., and Bolstad, P. V, 1996, Global Positioning System (GPS) Accuracies in Eastern U.S. Deciduous and Conifer Forests: v. 20, p. 81-84.

Dogwiler, T., and Wicks, C.M., 2004, Sediment entrainment and transport in fluviokarst systems: Journal of Hydrology, v. 295, p. 163-172.

Dreybrodt, W., and Gabrovsek, F., 2003, Basic processes and mechanisms governing the evolution of karst: Speleogenesis and Evolution of Karst Aquifers.

Engel, A. S., and Engel, S. A., 2009, A field guide for the karst of Carter Caves State Resort Park and the surrounding area, northeastern Kentucky, in Engel, A. S., and Engel, S. A., eds., Field Guide to Cave and Karst Lands of the United States, Karst Waters Institute Special Publication 15: Leesburg, VA, Karst Waters Institute, p. 154-171. 
Espinasa, L., and Borowsky, R., 2000, Eyed cave fish in a karst windows: Journal of Cave and Karst Studies, v. 62, p. 183.

Ferro-Famil, L., and Pottier, E., 2016, Synthetic Aperture Radar Imaging: Microwave Remote Sensing of Land Surfaces: Techniques and Methods, p. 1-65.

Ford, D. C., and Williams, P., 2007, Karst hydrogeology and geomorphology, Chichester, John Wiley \& Sons Ltd, 562 p.

Francis, A., Peterson, E.W., and Dogwiler, T.J., 2018, Lithology as an erosional control on the Cave Branch and Horn Hollow fluviokarst watersheds in Carter County, Kentucky: National Cave and Karst Research Institute, 279-288 p.

Girihagama, L., Nof, D., and Hancock, C., 2015, Bubble-induced cave collapse: PLOS ONE, v. 10 , p. $1-14$.

Granger, D.E., Kirchner, J.W., and Finkel, R.C., 1997, Quaternary downcutting rate of the New River, Virginia, measured from differential decay of cosmogenic 26Al and 10Be in cavedeposited alluvium: Geology, v. 25, p. 107-110.

Granger, D.E., Fabel, D., and Palmer, A.N., 2001, Pliocene - Pleistocene incision of the Green River, Kentucky, determined from radioactive decay of cosmogenic $26 \mathrm{Al}$ and10Be in Mammoth Cave sediments: Bulletin of the Geological Society of America, v. 113, p. 825836. 
Hammer, R.D., Young, F.J., Wollenhaupt, N.C., Barney, T.L., and Haithcoate, T.W., 1995 "Slope class maps from soil survey and digital elevation models," Soil Science Society of America Journal,vol. 59,no. 2, pp.509-519.

Harlan, L.E., and Dogwiler, T., 2009, Expanding the Conceptual Model for the Carter Caves.

Hill, C.A., and Polyak, V.J., 2014, Karst piracy: A mechanism for integrating the Colorado River across the Kaibab uplift, Grand Canyon, Arizona, USA: Geosphere, v. 10, p. 627-640.

Hobbs III, H.H., and Pender, M.M., 1985, HornHollowCave_Hobbs\&Pender1985.pdf: Pholeos, v. 5 , p. $17-22$.

Jacoby, B. S., Peterson, E. W., and Dogwiler, T., 2011a, Identifying the stream erosion potential of cave levels in Carter Cave State Resort Park, Kentucky, USA: Journal of Geographic Information Systems, v. 3, no. 4, p. 323-333.

Jacoby, B. S., Peterson, E. W., Dogwiler, T., and Kostelnick, J. C., 2011b, Estimating the timing of cave level development with GIS: Speleogenesis and Evolution of Karst Aquifers, v. 11, p. 52-61.

Jacoby, B.S., Peterson, E.W., Kostelnick, J.C., and Dogwiler, T., 2013, Approaching Cave Level Identification with GIS: A Case Study of Carter Caves: ISRN Geology, v. 2013, p. 1-7.

Jakucs L., 1977, Morphogenetics of karst regions: variants of karst evolution. New York: Wiley.

Jennings, J.A., 1985, Karst Geomorphology (B. Blackwell, Ed.): Oxford, v. 1, 151-152 p. 
Lollino, P., Martimucci, V., and Parise, M., 2013, Geological survey and numerical modeling of the potential failure mechanisms of underground caves: Geosystem Engineering, v. 16, p. $100-112$.

Mahalingam, R., Olsen, M.J., and O'Banion, M.S., 2016, Evaluation of landslide susceptibility mapping techniques using lidar-derived conditioning factors (Oregon case study): Geomatics, Natural Hazards and Risk, v. 7, p. 1884-1907.

Martin, J.B., and Dean, R.W., 2001, Exchange of water between conduits and matrix in the Floridan aquifer: Chemical Geology, v. 179, p. 145-165.

McGrain, P., 1966, Geology of Carter and Cascade Caves Area, Series X, Special Publication 12: Lexington, KY, Kentucky Geological Survey, University of Kentucky, p. 32.

Næsset, E., and Jonmeister, T., 2002, Assessing point accuracy of DGPS under forest canopy before data acquisition, in the field and after postprocessing: Scandinavian Journal of Forest Research, v. 17, p. 351-358.

Ochsenbein, G. D., 1974, Origin of caves in Carter Caves State Park, Carter County, Kentucky [Master's thesis]: Bowling Green State University, 64 p.

Palmer, A.N., 1991, Origin and morphology of limestone caves: Geological Society of America Bulletin, v. 103, p. 1-21.

Palmer, A.N., 2007. Year of the Tiankeng: National Speleological Society News, v. 65, p. 9-15. 
Parise, M., and Pascali, V., 2003, Surface and subsurface environmental degradation in the karst of Apulia (southern Italy): Environmental Geology, v. 44, p. 247-256.

Peterson, E., Dogwiler, T., and Harlan, L., 2011, Using GIS to identify cave levels and discern the speleogenesis of the Carter Caves karst area, Kentucky, in Kuniansky, E. L., ed., U.S. Geological Survey Karst Interest Group Proceedings, Fayetteville, Arkansas (April 26-29, 2011), Volume Scientific Investigations Report 2011-5031: Reston, Virginia, United States Geological Survey, p. 94-103.

Pfeffer, N., Madigan, T.J., and Hobbs III, H.H., 1981 "Laurel Cave," Pholeos, vol. 2, no. 1, pp. $10-11$.

Powell, R.L., 1970, Base level, lithologic, and climatic controls of karst groundwater zones in south-central Indiana: Indiana Academy of Sciences Proceedings, v. 79, p. 281-291.

Rodríguez-Pérez, J.R., Flor Álvarez, M., Sanz, E., Gavela, A., Rodríguez-pérez, J.R., Flor ÁLVAREZ, M., and GAVELA Spain, A., 2006, Comparison of GPS Receiver Accuracy and Precision in Forest Environments. Practical Recommendations Regarding Methods and Receiver Selection: XXIII FIG Congress, p. 16.

Sanders, W., 1981. Limestone Denudation. In M.M. Sweeting (Ed.) Karst Geomorphology: Benchmark Papers in Geology, Stroudsburg, Pennsylvania: Hutchinson Ross Publishing Company v. 59 (p. 320-343).

Sauro, U., 2019, Chapter 33 - Closed depressions in karst areas, in White, W.B., Culver, D.C., and Pipan, T.B.T.-E. of C. (Third E. eds., Academic Press, p. 285-300. 
Siemers, J., and Dreybrodt, W., 1998, Early development of karst aquifers on percolation networks of fractures in limestone: Water Resources Research, v. 34, p. 409-419.

Slocum, T.A., McMaster, R.B., Kessler, F.C., Howard, H.H., 2009, Thematic Cartography and Geovisualization. 3rd Edition. Upper Saddle River: Pearson-Prentice Hall.

Springer, G.S., Kite, J.S., Schmidt, V.A., 1997. Cave sedimentation, genesis, and erosional history in the Cheat River canyon, West Virginia. Geological Society of America Bulletin, v. 109 , p. $524-532$.

Springer, G.S., Poston, H.A., Hardt, B., and Rowe, H.D., 2015, Groundwater lowering and stream incision rates in the Central Appalachian Mountains of West Virginia, USA: International Journal of Speleology, v. 44, p. 99-105.

Sweeting, M.M., 1950, Erosion cycles and limestone caverns in the Ingle-borough District of Yorkshire, Geogr. Journal, v. 124, p. 63-78.

Thaler, E.A., and Covington, M.D., 2016, The influence of sandstone caprock material on bedrock channel steepness within a tectonically passive setting: Buffalo National River Basin, Arkansas, USA: Journal of Geophysical Research: Earth Surface, v. 121, p. 16351650.

Veal, M.W., Taylor, S.E., McDonald, T.P., McLemore, D.K. and Dunn, M.R., 2001, Accuracy of tracking forest machines with GPS. Trans. ASAE, v. 44, p. 1903-1911.

White, E.L., and White, W.B., 1983, Karst landforms and drainage basin evolution in the Obey River Basin, North-Cnetral Tennessee, U.S.A.: Journal of Hydrology, v. 61, p. 69-82. 
White, W.B., 1988, Geomorphology and hydrology of karst terrains: Geomorphology and hydrology of karst terrains.

Woodside, J., Peterson, E.W., and Dogwiler, T., 2015, Longitudinal profile and sediment mobility as geomorphic tools to interpret the history of a fluviokarst stream system: International Journal of Speleology, v. 44, p. 197-206.

Worthington, S.R.H., 2005, Evolution of caves in response to base-level lowering: Cave and Karst Science, v. 32, p. 3-12.

Zhang, X., Drake, N.A., Wainwright, J., and Mulligan, M., 1999. “Comparison of slope estimates from low resolution DEMS: scaling Issues and a fractal method for their solution," Earth Surface Processes and Landforms, vol.24, pp.763-779. 